\title{
A Sensitivity Analysis of Conservation Opportunities in the Irrigated Agriculture Sector of the Pacific Northwest
}
B. J. Harrer

July 1985

Prepared for

Bonneville Power Administration

Office of Conservation Planning under a Related Service Agreement with the U.S. Department of Energy Contract DE-AC06-76RLO 1830

Pacific Northwest Laboratory Operated for the U.S. Department of Energy by Battelle Memorial Institute 


\title{
DISCLAIMER
}

This report was prepared as an account of work sponsored by an agency of the United States Government. Neither the United States Government nor any agency thereof, nor any of their employees, makes any warranty, express or implied, or assumes any legal liability or responsibility for the accuracy, completeness, or usefulness of any information, apparatus, product, or process disclosed, or represents that its use would not infringe privately owned rights. Reference herein to any specific commercial product, process, or service by trade name, trademark, manufacturer, or otherwise, does not necessarily constitute or imply its endorsement, recommendation, or favoring by the United States Government or any agency thereof. The views and opinions of authors expressed herein do not necessarily state or reflect those of the United States Government or any agency thereof.

\author{
PACIFIC NORTHWEST LABORATORY \\ operated by \\ BATTELLE \\ for the \\ UNITED STATES DEPARTMENT OF ENERGY \\ under Contract DE-AC06-76RLO 1830
}

\begin{tabular}{|c|c|}
\hline \multicolumn{2}{|c|}{ Printed in the United States of America } \\
\hline \multirow{2}{*}{\multicolumn{2}{|c|}{$\begin{array}{l}\text { Available from } \\
\text { National Technical Information Service }\end{array}$}} \\
\hline & \\
\hline \multirow{2}{*}{\multicolumn{2}{|c|}{$\begin{array}{c}\text { United States Department of Commerce } \\
5285 \text { Port Royal Road } \\
\text { Springfield, Virginia } 22161\end{array}$}} \\
\hline & \\
\hline \multirow{2}{*}{\multicolumn{2}{|c|}{$\begin{array}{l}\text { NTIS Price Codes } \\
\text { Microfiche A01 }\end{array}$}} \\
\hline & \\
\hline \multicolumn{2}{|c|}{ Printed Copy } \\
\hline & Price \\
\hline Pages & Codes \\
\hline $001-025$ & A02 \\
\hline 026-050 & $\mathrm{A} 03$ \\
\hline 051-075 & A04 \\
\hline $076-100$ & A05 \\
\hline $101-125$ & A06 \\
\hline $126-150$ & $A 07$ \\
\hline $151-175$ & $\mathrm{~A} 0 \mathrm{~B}$ \\
\hline $176-200$ & $A 09$ \\
\hline 201-225 & A010 \\
\hline $226-250$ & A011 \\
\hline $251-275$ & A012 \\
\hline $276-300$ & $A 013$ \\
\hline
\end{tabular}


PNL -5525

UC $-95 \mathrm{C}$

\title{
A SENSITIYITY ANALYSIS \\ OF CONSERVATION OPPORTUNITIES \\ IN THE IRRIGATED AGRICULTURE \\ SECTOR OF THE PACIFIC NORTHWEST
}

\section{B. J. Harrer}

July 1985

\author{
Prepared for \\ Bonneville Power Administration \\ Office of Conservation Planning \\ under a Related Service Agreement with \\ the U.S. Department of Energy \\ Contract DE-AC06-76RLO 183D
}

Pacific Northwest Laboratory Richland, Washington 99352 


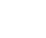

.

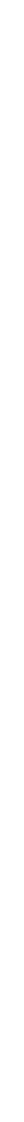




\section{SUMMARY}

This report summarizes the results of a sensitivity analysis of the cost effectiveness and energy-savings potential of conservation measures in the irrigation sector of the Pacific Northwest. This study is characterized as a sensitivity analysis because it examines the sensitivity of estimates of the cost effectiveness and energy-savings potential of conservation measures in the irrigation sector generated in a previous study (Harrer et al. 1985c) to changes in various types of input data parameters. These changes include reductions in purchase, installation and operating/maintenance costs for irrigation-sector conservation measures. Increases in the amounts of irrigation pumping head savings that would result from the use of the measures were also implemented in the sensitivity analysis.

The assumptions used in the sensitivity analys is cause the analysis to represent a "best-case" scenario for the amount of energy that can potentially be saved through the implementation of irrigation-sector conservation measures in the Pacific Northwest and the costs per kwh saved for obtaining these savings. Under these "best-case" assumptions, it is estimated that approximately 207 average megawatts of electricity can potentially be saved by the year 2003 through the implementation of low-pressure irrigation, pump fittings redesign, increases in mainline size, and improved irrigation scheduling on new and existing irrigated acres. The majority of these savings (70 percent) can be obtained for a cost of 20 mills per kwh saved or less. 
CONTENTS

SUMMARY

1.0 INTRODUCTION

2.0 RESULTS AND CONCLUSIONS

3.0 OVERVIEW OF ISEP MODEL METHODOLOGY .

3.1 LEVELIZED COST ESTIMATION

3.2 COST PER KWH SAVED ESTIMATES -

3.3 POTENTIAL ENERGY SAVINGS ESTIMATES .

3.4 SUPPLY CURVE ESTIMATES .

4.0 INPUT DATA FOR CONSERVATION MEASURE ANALYSES . REFERENCES

APPENDIX A

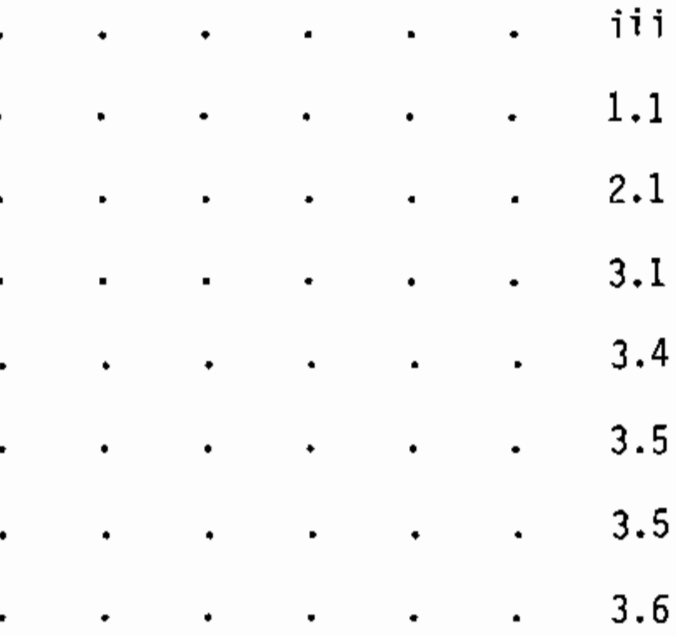

4.1

R. 1

A. 1

v 


\section{TABLES}

2.1 Surmary of the Results of a Sensitivity Analysis of Conservation

Measures in the Pacific Northwest Irrigation Sector . . . 2.2

2.2 Estimated Total Energy-Savings Potential in the Irrigation Sector in 5-Mill Increments of Cost Per kwh Saved . . . . . 2.3

4.1 Energy-Use Input Data Selected for Analyzing Conservation Measures on Center-Pivot Irrigation Systems . $. \quad . \quad$. $\quad . \quad$. 4.2

4.2 Energy-Use Input Data Selected for Analyzing Conservation Measures on Other Sprinkler Irrigation Systems . . . . . . . 4.3

4.3 Economic Parameters Used in Analyzing Conservation Measure Implementation on Existing Acres . $. \quad . \quad . \quad . \quad . \quad .4 .4$

4.4 Economic Parameters Used in Analyzing Conservation Measure Implementation on New Acres

4.5 Energy-Use Input Data for a Sensitivity Analysis of Conservation Measures on Center-Pivot Irrigation Systems . . . . . . 4.7

4.6 Energy-Use Data for a Sensitivity Analysis of Conservation Measures on Other Sprinkler Irrigation Systems . . . . . . 4.8

4.7 Economic Parameters for a Sensitivity Analysis of Conservation Measures Implementation on Existing Acres

4.8 Economic Parameters for a Sensitivity Analys is of Conservation Measure Implementation on New Acres

A.1 Estimated Energy-Savings Potential in Average MW and Cost Per kWh Saved in 1984 Mills for Low-Pressure Irrigation on Existing and New Center-Pivot Acres

A.2 Estimated Cumulative Energy-Savings Potential in 5-Mill Increments of Cost Per kWh Saved for Low-Pressure Irrigation on Existing Center $\rightarrow$ Pivot Acres

A.3 Estimated Cumulative Energy Savings Potential in 5-Mill Increments of Cost per kWh Saved for Low-Pressure Irrigation on New CenterPivot Acres

A.4 Estimated Energy-Savings Potential in Average MW and Cost Per kWh Saved in 1984 Mills for Low-Pressure Irrigation on Existing and New Handmove and Sideroll Acres

A.5 Estimated Cumulative Energy Savings Potential in 5-Mill Increments of Cost Per kwh Saved for Low-Pressure Irrigation on Existing Handmove and Sideroll Acres 
A.6. Estimated Cumulative Energy Savings Potential in 5-Mill Increnents of Cost per kWh Saved for Low-Pressure Irrigation on New Handmove and Sideroll Acres . . . . . . . . . . .

A.7 Estimated Energy-Savings Potential in Average MW and Cost Per kWh Saved in 1984 Mills for Fittings Redesign on Existing and New Center-Pivot Acres

A.8 Estimated Cumulative Energy-Savings Potential in 5-Mill Increments of Cost Per kWh Saved for Fittings Redesign on Existing CenterPivot Acres

A.9 Estimated Cumulative Energy Savings Potential in 5-Mill Increments of Cost per kWh Saved for Fittings Redesign on New Center-Pivot Acres

A.10 Estimated Energy-Savings Potential in Average MW and Cost Per KWh Saved in 1984 Mills for Fittings Redesign on Existing and New Other Sprinkler Acres

A.11 Estimated Cumulative Energy Savings Potential in 5-Mill Increments of Cost Per kWh Saved for Fittings Redesign on Existing Other Sprinkler Acres

A.12 Estimated Cumulative Energy Savings Potential in 5-Mill Increments of Cost per kWh Saved for Fittings Redesign on New Other Sprinkler Acres

A.13 Estimated Energy-Savings Potential in Average MW and Cost Per kWh Saved in 1984 Mills for Mainline Modification on Existing and New Center-Pjvot Acres

A.14 Estimated Cumulative Energy-Savings Potential in 5-Mill Increments of Cost Per kWh Saved for Mainline Modification on Existing

Center $\rightarrow$ Pivot Acres

A.15 Estimated Cumulative Energy Savings Potential in 5-Mill Increments of Cost per kWh Saved for Mainline Modification on New CenterPivot Acres

A.16 Estimated Energy-Savings Potential in Average MW and Cost Per kWh Saved in 1984 Mills for Mainline Modification on Existing and New 0 ther Sprinkler Acres

A.17 Estimated Cumulative Energy-Savings Potential in 5-Mill Increments of Cost Per kWh Saved for Mainline Modification on Existing Other Sprinkler Acres

A.18 Estimated Cumulative Energy Savings Potential in 5-Mill Increments of Cost per kWh Saved for Mainline Modification on New Other Sprinkler Acres 
A.19 Estimated Energy-Savings Potential in Average MW and Cost Per kWh Saved in 1984 Mills for Improved Scheduling on Existing and New Center-Pivot Water-Sensitive Crop Acres . . . . .

A.20 Estimated Cumulative Energy-Savings Potential in 5-Mill Increments of Cost Per kWh Saved for Improved Scheduling on Existing CenterPivot Water-Sensitive Crop Acres

A.21 Estimated Cumulative Energy Savings Potential in 5-Mill Increments of Cost per kWh Saved for Improved Scheduling on New Center-Pivot Water-Sensitive Crop Acres

A.22 Estimated Energy-Savings Potential in Average MW and Cost Per KWh Saved in 1984 Mills for Improved Scheduling on Existing and New Center-Pivot Non-Water-Sensitive Crop Acres . . . .

A.23 Estimated Cumulative Energy-Savings Potential in 5-Mill Increments of Cost Per kWh Saved for Improved Scheduling on Existing CenterPivot Non-Water-Sensitive Crop Acres . . . . . . .

A.24 Estimated Cumulative Energy Savings Potential in 5-Mill Increments of Cost per kWh Saved for Improved Scheduling on Center-Pivot NonWater-Sensitive Crop Acres . . . . . . . .

A.25 Estimated Energy-Savings Potential in Average $M W$ and Cost Per kWh Saved in 1984 Mills for Improved Scheduling in Existing and New Other Sprinkler Water-Sensitive Crop Acres . . . .

A.26 Estimated Cumulative Energy-Savings Potential in 5-Mil] Increments of Cost Per kWh Saved for Improved Scheduling on Existing Other Sprinkler Water-Sensitive Crop Acres . . . . .

A.27 Estimated Cumulative Energy Savings Potentia] in 5-Mill Increments of Cost per kWh Saved for Improved Scheduling on New Other Sprinkler Water-Sensitive Crop Acres

A.28 Estimated Energy-Savings Potential in Average MW and Cost Per kWh Saved in 1984 Mills for Improved Scheduling on Existing and New Other Sprinkler Non-Water-Sensitive Crop Acres . . .

A.29 Estimated Cumulative Energy-Savings Potential in 5-Mill Increments of Cost Per kWh Saved for Improved Scheduling on Existing Other Sprinkler Non-Water-Sensitive Crop Acres

A.30 Estimated Cumulative Energy Savings Potential in 5-Mill Increments of Cost per kWh Saved for Improved Scheduling on New Other Sprinkler Non-Water-Sensitive Crop Acres 


\subsection{INTRODUCTION}

The irrigated agriculture sector of the Pacific Northwest has been targeted by the Pacific Northwest Power Planning Council and the Bonneville Power Administration (BPA) as one of the areas where cost-effective electricity savings can potentially be obtained through the application of various types of conservation measures. In an earlier BPA-sponsored study of the costs and availability of these savings, a computer model known as the Irrigation Sector Energy Planning (ISEP) model was developed by Pacific Northwest Laboratory (PNL) personnel (Harrer et al. 1985c). Variods types of data on the characteristics of conservation measures in the irrigazion sector were input to the ISEP model, and output results were obtained that were subsequently incorporated in BPA planning activities.

A conservative approach was generally followed in performing the origine study of the costs and energy-savings potential of conservation measures in t'e irrigation sector for BPA. That is, the cost input data on conservation measures provided to the ISEP model were in the high range of available estimates, and the energy savings input data were in the low range of availat e estimates. This conservative approach was requested by BPA so that the predicted levels of energy savings and their costs could be relied upon with high degree of certainty.

After the results of the original study were developed, BPA requested t.l it a sensitivity analysis of these results be performed using cost irput data selected from the low range of available estimates and energy savings input data selected from the high range of available estimates. By providing estimates of the energy-savings potential and cost effectiveness of irrigati 11 conservation measures under a "best-case" scenario, this analysis will provil an indication of the range in energy-savings potential and cost effectivene; of conservation measures in the irrigation sector. The purpose $0^{*}$ this repijt is to describe the input data used in the sensitivity analysis and document " ne results of the analysis.

This report is divided into four sections. The second section provides a brief overview of the methodology employed in the ISEP model for evaluating : he cost effectiveness and energy-savings potential of conservation measures in : he 
irrigation sector. In the third section, the input data used in both the original study of irrigation conservation measures and the sensitivity analysis are described. The final chapter presents a summary of the results of the sensitivity analysis and highlights the major differences between these results and those obtained in the original study. 


\subsection{RESULTS ANO CONCLUSIONS}

A summary of the results of the sensitivity analysis of conservation measures in the irrigation sector of the Pacific Northwest is presented in Table 2.1. These results indicate that the potential-energy savings on new acres increase by only 8.6 average $M W$ in going from the low range of energy savings estimates for conservation measures developed in the original study (Harrer et al. 1985c) to the high range of energy savings estimates. The potential energy savings on existing acres increase by 39.4 average MW compar.d to the original study by using the high range of energy savings estimates.

The impacts on the cost effectiveness of conservation measures from varying the energy savings and economic input data used to analyze the measur:s are generally more significant than the impacts on the energy-saviags potent 111 of the measures. The average levelized costs per $k$ Wh saved are reduced by $m e$ than 25 percent in the sensitivity analysis compared to the original study $\mathrm{ft}_{\mathrm{f}}$ all conservation measures except low-pressure irrigation on existing handmove and sideroll systems, and in many cases the reductions in costs per kWh saver approach 50 percent. Under the assumptions of the sensitivity analysis, all if the conservation measures in the irrigation sector, except improved schedulir 1 , have average costs per $k$ wh saved of less than $15 \mathrm{mills}$.

Results presented in Table 2.2 indicate that, under the assun'ptions of ' sensitivity analysis, over 35 percent of the total potential enercy savings $\cdots 1$ all acres in the irrigation sector can be obtained for a cost of $10 \mathrm{mills}$ pe* kWh saved or less. Over 70 percent of all savings can be realizec for $20 \mathrm{mi}$ is per $k$ th saved or less, and over 85 percent of total savings are available fo" a cost of $30 \mathrm{milis}$ per $\mathrm{kWh}$ saved or less. Only 10 percent of the total potent al savings would cost more than $50 \mathrm{mills}$ per $k$ th saved to obtain.

Detailed measure-specific data on the results of the sensitivity analys; are presented in Appendix A. These numbers can be compared to data presente in Chapter 6.0 of the original study (Harrer et al. 1985c) to eva uate in detail the impacts on individual conservation measure cost effect veness anc energy-savings potential of using energy savings input data selected from th high range of available estimates and cost input data selected from the low range of available estimates. 
TABLE 2.1. Summary of the Results of a Sensitivity Analysis of Conservation Measures in the Pacific Northwest Irrigation Sector

Tota] Potential Energy Savings (Avg. MW) Average Levelized Cost Per kWh Saved (Mills)

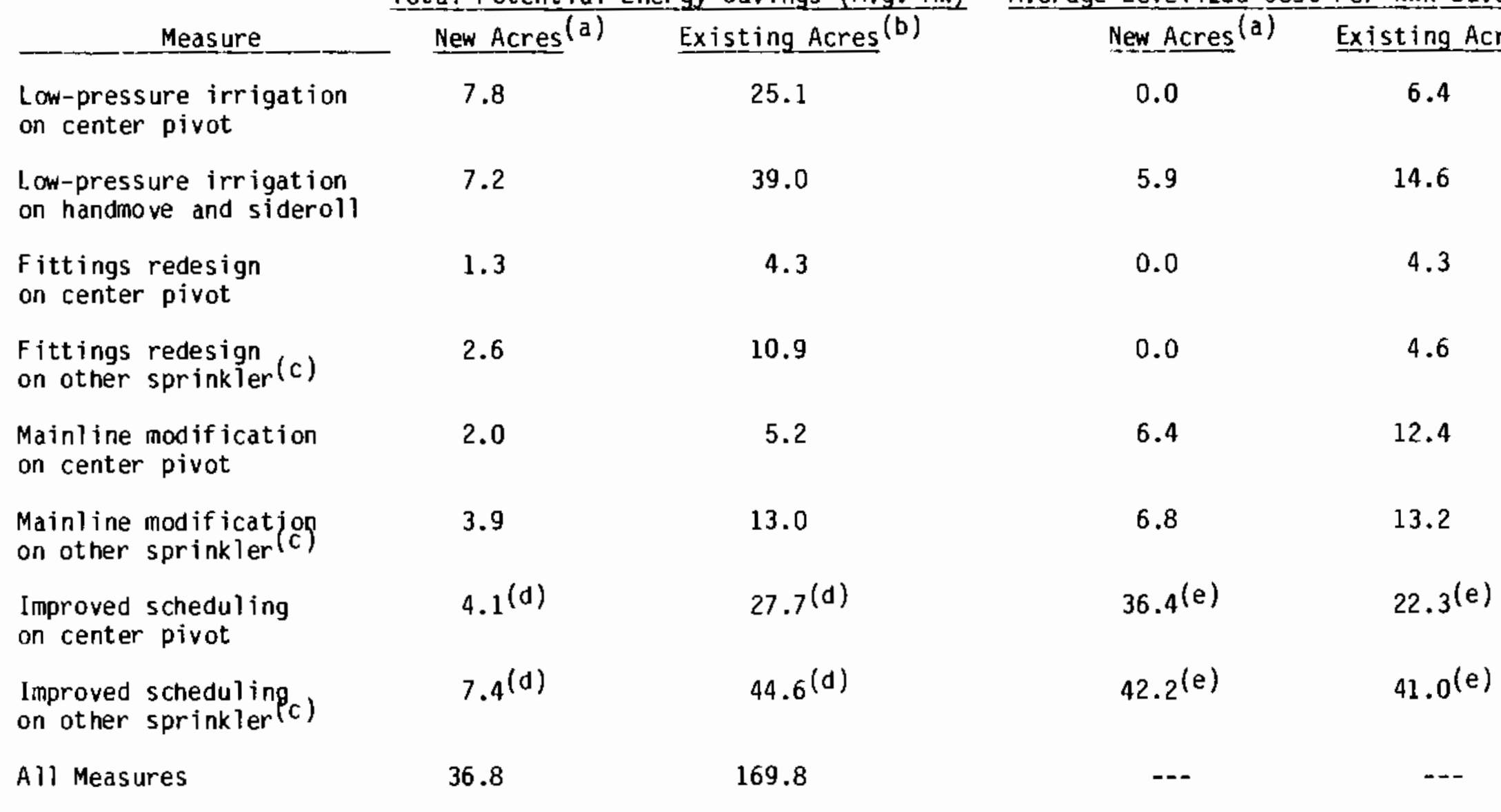

(a) All estimates shown for new acres are for the end of the forecast period (2003).

(b) All estimates shown for existing acres are for the beginning of the forecast period (1984).

(c) Other sprinkler includes acres irrigated by handmove, sideroll, and solid-set sprinklers.

(d) Savings estimates shown here represent the sum of savings on water sensitive and non-water sensitive crop acres.

(e) Significant differences were found between groundwater and surface water acres in cost per kWh saved for improved scheduling. 
TABLE 2.2. Estimated Total Energy-Savings Potential in the Irrigation Sector in 5-Mill Increments of Cost Per kWh Saved

Total Energy Savings Potential (Avg. MW) on Existing Acres

Total Energy Savings Potential (Avg. MW)

15.2

15.

$24.3 \quad 25.2$

26.8

28.8

30.4

$-35$.

40

$45 \quad-50$

on New Acres

in 2003 


\subsection{OVERVIEW OF ISEP MODEL METHODOLOGY}

The ISEP model developed by PNL personnel to estimate the cost effectiveness and energy-savings potential of conservaiton measures in irrigated agriculture combines both engineering and economic principles. It simulates the energy-use process of irrigation systems, uses a levelized costing routine to derive estimates of the annual costs of investments in conservation measures, and then combines the two steps to estimate a cost per $k$ Wh saved for conservation investments. The energy savings estimares are the aggregated in 5-mill increments of cost per $k$ th saved to develop supply curve: for conservation measures in the irrigation sector. The major feazures of tr: model are described in this section.

The kWh electrical energy use of an irrigation system is estinated in tr ISEP model using the following equation:

$$
E=\frac{V \times H \times 1.024}{P P E}
$$

where $E$ = annual electrical energy use per acre in kWh for an irrigation system

$V=$ volume of water applied annually through the irrigation system in acre feet

$H=$ total dynamic head of the irrigation system in feet $P P E=$ efficiency of the pumping plant in converting energy input into energy output

The above equation is a reduced form of a standard equation that represents the relationship between the amount of irrigatin water moved and ne energy required to move it. The use of the above equation to calculate the electrical energy demand of an irrigation system is supported by a number of other studies (e.g., Bonneville Power Administration 1983 and Patton et al. 1982).

The volume of water applied ( $V$ ) that is input into the energy demand equation represents the actual amount of water that is distributed through a" irrigation system. It is a function of a number of different factors, 
including climatic conditions, crop type, soil type, and the efficiency of the water application system. The total dynamic head of an irrigation system is the sum of:

1. the amount of pumping $1 \mathrm{ift}$ that has to be overcome to move the irrigation water from its source point to field level

2. the amount of pressure required to operate the irrigation system at its design pressure.

The efficiency of a pumping plant is a function of both the efficiency of the motor used to drive the pump and the efficiency of the pump itself. The product from multiplying the two efficiencies represents the overall pumping plant efficiency.

In the context of Equation 3.1, energy conservation measures decrease the energy use of an irrigation system by either reducing $H$, reducing $V$, or increasing PPE. It follows then that the impact of an energy conservation measure upon the energy use per acre for irrigation can be estimated using the following general equation:

$$
\Delta E=\frac{V_{0} \times H_{0} \times 1.024}{P P E_{0}}-\frac{V_{1} \times H_{1} \times 1.024}{P P E_{1}}
$$

where $\Delta E=$ difference in kWh energy use per acre between an jrrigation system that incorporates an energy conservation measure and one that does not incorporate an energy conservation measure $V_{0}, H_{0}, P P E_{0}=$ voiume of water applied, total dynamic head, and pumpingplant efficiency of an irrigation system before a conservation measure is implemented

$V_{1}, H_{1}, P P E_{1}=$ volume of water applied, total dynamic head, and pumpingplant efficiency of an irrigation system after a conservation measure is implemented

To avoid over-estimation of the potential energy savings that will result from implementation of conservation measures, it is important to account for interactions between individual conservation measures that cause the total energy savings resulting from implementation of several measures to be less 
than the sum of the savings for the individual measures. For example, suppos: that a conservation measure that reduces $V$ is implemented on an irrigation system after a conservation measure that reduces $H$. To avoid double counting of conservation-measure energy savings, the estimated energy savings for the conservation measure that reduces $V$ should be estimated based upon the reduce $H$ that was achieved using the previously implemented conservation measure.

The ISEP model has the ability to incorporate the interactive effects of individual conservation measures through a model-user specified implementatic'l priority system. This priority system orders estimation of the energy-savinc:. potential of conservation measures so that the potential energy savings estimates for each measure are based upon an irrigation system that incorporates all previously implemented conservation measures.

The per-acre energy savings estimates caiculated using Equation 3.2 are also adjusted to account for any inconsistencies between the total energy use estimates of the ISEP model and BPA's irrigation load forecasts. This adjustment is performed using the following equation:

Adj $\Delta E=\Delta E \times$ Ratio

where $\operatorname{Adj} \Delta E=$ adjusted difference in $k$ wh energy use per acre between an irrigation system that incorporates an energy conservation measure and one that does not inrorporate an energy conserwation measure

$\Delta E=$ as defined in Equation 3.2

Ratio = ratio of the total regional energy use estimate from BPA's icad forecasting mooel to the total regional energy use estimate calculated by ISEP, minus estimated price-induced conservaticn from BPA's load forecasting model

In general, the total energy use estimates from BPA's load forecasting model were within 10 percent of those calculated by ISEP, minus the load forecasting model's estimate of price-induced conservation. Thus, the impact: of the adjustment factor, Adj $\Delta E$, on the energy savings estimates for the various conservation measures is small. 


\subsection{LEVELIZED COST ESTIMATION}

The impact of a conservation measure on irrigation system costs per acre is estimated in the model using the following general equation:

$$
\begin{aligned}
\Delta L E V & =\text { LEV }_{1}-L E V_{0} \\
& =\left[\left(I_{1}-\frac{S V_{1}}{(1+d)^{n}}\right)\left(\frac{d(1+d)^{n}}{(1+d)^{n}-1}\right)\right]-\left[\left(I_{0}-\frac{S V_{0}}{(1+d)^{m}}\right)\left(\frac{d(1+d)^{m}}{(1+d)^{m}-1}\right)\right] \\
& +\left[\left(\text { PVOM }_{1}\right)\left(\frac{d(1+d)^{n}}{(1+d)^{n}-1}\right)\right]-\left[\left(\text { PVOM }_{0}\right)\left(\frac{d(1+d)^{n}}{(1+d)^{n}-1}\right)\right]
\end{aligned}
$$

where $\triangle L E V=$ difference in the annual equivalent or levelized cost between an irrigation system without implementation of a conservation measure and a system with implementation of a conśervation measure

$I_{1}=$ initial capital cost of investing in an irrigation system that incorporates a conservation measure

$S V_{1}=$ salvage value for equipment installed as part of implementing a conservation measure

$d=$ discount rate used for converting present initial capital costs to annual equivalent (levelized) costs

$n=$ system life for a conservation measure

$I_{0}=$ initial capital cost of investing in an irrigation system that does not incorporate a conservation measure

$S V_{0}=$ salvage value for equipment of an irrigation system before implementation of a conservation measure

$m$ = system 1 ife for an irrigation system before implementation of a conservation measure

PVOM $_{1}=$ present value of operation and maintenance costs for an irrigation system that incorporates a conservation measure PVOM $_{0}=$ present value of operation and maintenance costs for an irrigation system that does not incorporate a conservation measure 
The equation listed above deviates from many levelized cost equations in that annual operation and maintenance costs are converted to present value terms a'id then levlized over the expected life of the irrigation system. This feature was incorporated in the calculation procedures to account for the possibility of annual operation and mantenance expenses varying over the life of the irrigation system.

\subsection{COST PER KHH SAVED ESTIMATES}

Once the impact of a conservation measure on irrigation system levelizec cost and energy use per acre has been calculated, the cost per $k$ wh saved for the conservation measure is calculated using the following equation:

$$
\text { Cost per } k W h \text { saved }=\frac{\Delta L E V}{\Delta E}
$$

where $\Delta E=$ difference in $k$ Wh energy use between an irrigation system that incorporates an energy conservation measure and one that does no:. incorporate an energy conservation measure

$\Delta L E V=$ difference in annual equivalent or levelized cost between an irrigation system with a conservation measure and a system withi it a conservation measure

Cost per $\mathrm{kWh}$ saved estimates for each conservation measure are developect. using Equation 3.5, by type of crop being irrigated, water source used, and tipA subregion. In order to develop more aggregate estimates of cost per $k$ Wh saved, a series of equations was developed to calculate weighted averages of the estimates obtained from Equation 3.5 .

\subsection{POTENTIAL ENERGY SAVINGS ESTIMATES}

Estimates of the potential energy savings that could result from implementation of conservation measures in the regional irrigation sector ar: calculated in the ISEP model using the following equation:

Potential savings in average $M W=\Delta E \times(A C E L-A C C A) / 1000 / 8760$
for each conservation measure 
where $A C E L=$ new and existing acreage eligible to utilize a conservation measure (i.e., not 1 imited by technical considerations)

$A C C A=$ acreage on which a conservation measure has already been implernented

$\Delta E=$ as defined in Equation 3.2

$1000,8760=$ factors for converting $\mathrm{kWh}$ savings to average MW of savings

Two limiting factors are placed on the acres that are used to calculate aggregate potential energy savings in the model. The first limit is that technical constraints to implementing a conservation measure on specific types of acres are accounted for. Possible examples of technical constraints are soils that are too heavy or fields that have too much slope to allow for the use of a specific conservation measure. The second limit on acres involves accounting for the number of acres on which a conservation measure has already been implemented. For power planning purposes, acres on which a conservation measure has already been implemented should not be included in estimating the potential energy savings that are still available from the use of this measure. Thus, before potential energy savings estimates are calculated, the estimated number of acres on which each conservation measure has been implemented is subtracted from the number of acres technically eligible for each measure.

\subsection{SUPPLY CURVE ESTIMATES}

A supply curve for a conservation measure represents the amount of potential energy savings available from the measure at a given price per kWh saved at a given point in time. In the ISEP model, potential energy savings estimates in a supply curve are defined for 5-mill increments of cost per kWh saved. That is, for each 5-mill increase in the cost per kWh saved for a conservation measure up to a maximum of $50 \mathrm{mills}$ per $\mathrm{kWh}$, an estimate of the potential energy savings in average $M W$ for the measure is developed. The supply curve estimates are calculated in ISEP simply by agregating all of the estimated energy savings for a conservation measure (calculated by Equation 3.6) that can be obtained for a specified level of cost per $k$ wh saved (calculated by Equation 3.5). 


\subsection{INPUT DATA FOR CONSERVATION MEASURE ANALYSES}

The conservation measures selected for anaiysis as to their cost effectiveness and energy-savings potential in the Pacific Northwest irrigatiı:n sector include:

- low-pressure irrigation on center-pivot and handmove/sideroll sprinkler systems

- fittings redesign on all types of sprinkler systems

o mainline modification on all types of sprinkler systems

- improved irrigation scheduling on all types of sprinkler systems.

Low-pressure irrigation reduces irrigation energy use by requiring lowt. application pressures for water distribution than traditional high-pressure sprinkler application systems. Thus, the total dynamic head $(H)$ is reduced oy the use of low-pressure irrigation. Fittings redesign and mainline modification reduce friction losses within a sprinkler irrigatior piping sy :em and, thus, also serve to reduce total dynamic head $(H)$ requiremerts for irrigation. Improved irrigation scheduling reduces the water application volumes (V) required for irrigation. More detailed descriptions of these conservation measures are presented in other reports for those desiring additional information (Harrer and Lezberg 1984a, Harrer and Wilfert 1985a, Harrer and Lezberg 1985b, and Harrer et al. 1985c).

The input data used in the original study for BPA (Harrer et al. 1985c' of the conservation measures listed above are shown in Tables 4.1 through 4.4 . The data were obtained from estimates provided by various published and unpublished sources. These estimates are all based upon actual field experience with the various conservation measures, and most of the estimate! were obtained from sources located within the Pacific Northwest region. Th: energy-use data selected for the original study and shown in Tables 4.1 and 4.2 were generally in the low range of available estimates while the selected economic data (shown in Tables 4.3 and 4.4 ) were generally in the high rangrs of available estimates.

The input data selected for use in the sensitivity analysis were deriviad from the same information sources as the data used in the original study. 
TABLE 4.1. Energy-Use Input Data Selected for Analyzing Conservation Measures on Center-Pivot Irrigation Systems

Conservation
Measure

Low-Pressure Irrigation

Fittings Redesign

Mainline Modification

Improved Scheduling

Total Application
Head (feet) Before
Measure Implemented

$170^{(\mathrm{a})}$
$110^{(\mathrm{d})}$
$103^{(\mathrm{f})}$
$90^{(\mathrm{h})}$

Total Application Head (feet) After Measure Implemented

$$
\begin{aligned}
& 110^{(b)} \\
& 103^{(e)} \\
& 90^{(9)}
\end{aligned}
$$

\section{Volume of Water Applied Before Measure Implemented}

$100 \%$ of baseline ${ }^{(c)}$

$100 \%$ of baseline

$100 \%$ of baseline

$100 \%$ of baseline
Volume of Water Applied After Measure Implemented

$100 \%$ of baseline

$100 \%$ of baseline

$100 \%$ of baseline

$88 \%$ of baseline $(i)$ on orchard

$80 \%$ of baseline on potatoes

$78 \%$ of baseline on all other crops

(a) Assumes a design operating pressure of $54 \mathrm{psj}$ (125 feet of head) for high-pressure sprinkler head, 35 feet of frictional head loss, and 10 feet of elevation head loss.

(b) Assumes a design operating pressure of $28 \mathrm{psi}$ (65 feet of head) for a low-pressure spray application head, 35 feet of frictional head loss, and 10 feet of elevation head loss, and is derived from analyzing data obtained from numerous published and unpublished sources including personal communications with Mike Monaghan, Merlin Jensen and Bruce Hurtado.

(c) Baseline water application volumes are estimates of current water application amounts by subregion and crop and were obtained by analyzing historical data from the United States Bureau of Reclamation.

(d) Assumes low-pressure irrigation already has been implemented.

(e) Assumes implementation of fittings redesign will reduce total dynamic head by an average of approximately 7 feet and is derived from an analysis of BPA irrigation system audit records supplied by Terry Henderson and results developed by Shearer (Shearer 1983).

(f) Assumes fittings redesign has already been implemented.

(g) Assumes implementation of mainline modification will reduce total dynamic head by an average of approximately 13 feet and is derived from an analysis of BPA irrigation system audit records supp]ied by Terry Henderson.

(h) Assumes all other conservation measures have been implemented.

(i) Assumes improved irrigation scheduling will reduce water application volumes by $12 \%$ on orchard crops, $20 \%$ on potatoes, $22 \%$ on all other crops and is derived from analys is of the results of numerous field studies (including Lord 1981 and Green 1982) and personal communication with various experts on irrigation scheduling, including Fred Ziari. 
TABLE 4.2. Energy-Use Input Data Selected for Analyzing Conservation Measures on Other Sprinkler Irrigation Systems

Conservation Measure

Low-Pressure Irrigation

Fittings Redesign

Mainline Modification

Improved Scheduling
Tot al Application

Head (feet) Bef ore

Measure Implemented

$$
\begin{aligned}
& 150^{(a)} \\
& 115^{(d)} \\
& 108^{(f)} \\
& 95^{(h)}
\end{aligned}
$$

Total App 1 ication
Head (feet) After
Measure Implemented

$$
115^{(b)}
$$

95
Volume of water Applied Before Measure Implemented $100 \%$ of baseline $(c)$ $100 \%$ of baseline $100 \%$ of baseline $100 \%$ of baseline
Volume of Water Applied After Measure Implemented

$100 \%$ of baseline

$100 \%$ of baseline

$100 \%$ of baseline

$93 \%$ of baseline $(i)$ on orchard

$89 \%$ of baseline on potatoes

88\% of baseline on all other crops

(a) Asumes a design operating pressure of $50 \mathrm{psi}$ (115 feet of head) for a high-pressure impact sprinkler head, 25 feet of frictional head loss, and 10 feet of elevation head.

(b) Assumes a design operating pressure of $35 \mathrm{psi}$ ( 80 feet of head) for a low-pressure impact application head, 25 feet of frictional head loss, and 10 feet of elevation head loss, and is derived from analyzing data obtained from numerous published and unpublished sources including personal communications with Dennis Kincaid and Carl Bronson.

(c) Baseline water application volumes are estimates of current water application amounts by subregion and crop and were obtained by analyzing historical data from the United States Bureau of Reclamation.

(d) Assumes low-pressure irrigation has already been implemented.

(e) Assumes implementation of fittings redesign will reduce total dynamic head by an average of approximately 7 feet and is derived from an analysis of BPA irrigation system audit records supplied by Terry Henderson and results developed by Shearer (Shearer 1983).

(f) Assumes fittings redesign has already been implemented.

(g) Assumes implementation of mainline modification will reduce total dynamic head by an average of approximately 13 feet and is derived from an analysis of BPA irrigation system audit records supplied by Terry Henderson.

(h) Assumes all other conservation measures have been implemented.

(i) Assumes improved scheduling will reduce water application volumes by $7 \%$ on orchard crops, $11 \%$ on potatoes, and $12 \%$ on all other crops, and is derived by arbitrarily reducing scheduling effectiveness estimates obtained in several field studies (including Lord 1981 and Green 1982) and personal comnuication with various experts on irrigation

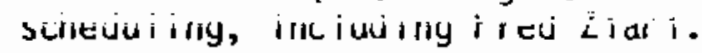


TABLE 4.3. Economic Parameters Used in Analyzing Conservation

Measure Implementation on Existing Acres

Conservation Measure

\begin{tabular}{|c|c|c|c|c|}
\hline $\begin{array}{l}\text { Low-Pressure } \\
\text { Irrigation on } \\
\text { Center-Pivot }\end{array}$ & $\begin{array}{c}\text { Low-Pressure } \\
\text { Irrigation on } \\
\text { Handmove/Sideroll }\end{array}$ & $\begin{array}{l}\text { Fittings } \\
\text { Redesign }\end{array}$ & $\begin{array}{l}\text { Mainline } \\
\text { Modification }\end{array}$ & $\begin{array}{l}\text { Improved } \\
\text { Scheduling }\end{array}$ \\
\hline
\end{tabular}

Purchase and Installation $\$ 31$ on surface water $\$ 15$ on surface water Cost per Acre $(\$ 1984)(\mathrm{a}) \quad \$ 42$ on groundwater $\$ 26$ on groundwater

Incrementa] Operation and Ma intenance Cost per Acre (\$1984)

Expected Lifetine of
Measure (years) $(\mathrm{c})$

Real Discount Rate $\left(x^{(d)}\right.$
0
1

20

3
$\$ 3.75$ on both surface and groundwater

0

3
$\$ 15.00$ on both surface and groundwater

0

20

NA

3

(a) All purchase and installation costs include the costs of installing low-pressure single spray heads on center-pivot systems, low-pressure impact heads on handmove and sideroll systems (end-guns on center-pivots, where necessary), and performing any required pump modifications, including pump replacement (where necessary). Fittings redesign costs include both labor and material costs. Mainline modification includes the cost of burying the mainline. (Sources of purchase and installation cost data include personal communications with Bruce Hurtado, Mike Monaghan and Jeff Raleigh for low-pressure irrigation; BPA Pilot Program records for fittings redesign; and personal communication with Byron Wood and Don Mulkey for mainline modification).

(b) Incremental operation and maintenance costs for low-pressure irrigation on handmove and sideroll systems is associated with the use of offsetting. Incremental 0\&M costs for improved scheduling are based on an annual peracre charge for all scheduling services and were obtained by analyzing data from several sources including personal communications with Joe Lord and Umatilla Electric Co-op representatives.

(c) No justification was found for specifying expected measure lives of less than 20 years for any of the conservation measures. Measure life is not applicable for improved scheduling because its cost is based upon an annual per-acre charge.

(d) Specified by BPA for conservation measure cost analyses. 
TABLE 4.4. Economic Parameters Used in Analyzing Conservation Measure Implementation on New Acres

Conservation Measure

$\begin{array}{lcc}\text { Low-Pressure } & \text { Low-Pressure } & \\ \text { Irrigation on } & \text { Irrigation on } & \text { Fittings } \\ \text { Center-Pivot } & \text { Mandmove/Sideroll } & \text { Redesign } \\ \text { Modification }\end{array}$

Improved Scheduling

Purchase and Installation

0

0

0

8.25

0

Incremental 0peration and

Maintenance Cost per Acre $(\$ 1984)^{(b)}$

0

1

0

0

6

$p$

Expected Lifetine, of

NA

Rea 1 Discount Rate (\%) (d)

3

3

3

3

(a) No additional equipment purchase and installation costs were found to be associated with any of the conservation measures except mainline modification and improved irrigation scheduling. Estimated cost for mainline modification is based upon the cost of purchasing the additional mainline materials only and does not include the cost of burying the mainline.

(b) All incremental operation and maintenance costs on new acres are estimated to be equal to those on existing acres.

(c) Measure jife on new acres is estimated to be equal to those on existing acres.

(d) Specified by gon for consoryation measure cost analycec. 
However, the selected energy savings input data were taken from the high range of available estimates, and the selected economic input data were taken from the low range of available estimates. The data selected for use in the sensitivity analysis are shown in Table 4.5 through 4.8 .

Note from Table 4.5 that the reduction in total application head resuting from implementation of low-pressure irrigation on center pivots was increased by 10 feet (approximately $4 \mathrm{psi}$ ) in the sensitivity analysis. A representative total application head of 100 feet corresponds to an application pressure for low-pressure single-spray application heads of approximately 24 psi or 55 feet of head. The total application head for low-pressure irrigation (presented in Table 4.6) is unchanged from that used in the original sutdy because design application pressures below 35 psi will generally not provide acceptable water distribution uniformity on such systems, according to available studies (e.g., Kincaid 1982).

The reduction in total application head resulting from implementation of fittings redesign was increased by 5 feet in the sensitivity analysis for both center-pivot and other sprinkler systems. The head reduction for mainline modification was also increased by 5 feet on both systems.

Water volume reductions resulting from improved irrigation scheduling on center pivots were increased by 2 percentage points on orchard crops and 8 percentage points on all other crops in the sensitivity analysis. Water volume reductions for improved scheduling on other sprinkler systems were increased by 5 percentage points on orchard crops, 9 percentage points on potatoes and 10 percentage points on all other crops. These increases restored the water volume reductions for improved scheduling on other sprinkler systems to the levels used for center pivots in the original study.

A1l purchase and installation costs for the conservation measures were reduced in the sensitivity analysis. Conservation measure incremental operation and maintenance costs were also reduced. The costs selected for use in the sensitivity analysis are all within the low end of the range of available estimates. 
TABLE 4.5. Energy-Use Input Data for a Sensitivity Analysis of Conservation Measures on Center-Pivot Irrigation Systems

Conservation Measure

Low-Pressure Irrigation

Fittings Redesign

Mainline Modification

Improved Scheduling
Total Application

Head (feet) Before

Measure Implemented

$$
\begin{aligned}
& 170^{(d)} \\
& 100^{(d)} \\
& 88^{(f)} \\
& 70^{(h)}
\end{aligned}
$$

Total Application

Head (feet) After

Measure Implemented

$$
\begin{aligned}
& 100^{(b)} \\
& 88^{(e)} \\
& 70(g)
\end{aligned}
$$

Volume of Water Applied Before Measure Implemented $100 \%$ of baseline (c) $100 \%$ of baseline $100 \%$ of baseline $100 \%$ of baseline
Volume of Water Applied After Measure Implemented

$100 \%$ of baseline

$100 \%$ of baseline

$100 \%$ of baseline

$86 \%$ of baseline( $(i)$ on orchard

\section{$72 \%$ of baseline} on potatoes

$70 \%$ of baseline on all other crops

(a) Assumes a design operating pressure of $54 \mathrm{psi}$ (125 feet of head) for a high-pressure sprinkler head, 35 feet of frictional head loss, and 10 feet of elevation head loss.

(b) Assumes a design operating pressure of $24 \mathrm{psi}$ ( 55 feet of head) for a low-pressure spray application head, 35 feet of frictional head loss, and 10 feet of elevation head loss, and is derived from analyzing data obtained from numerous published and unpublished sources, including personal communication with Mike Monaghan, Merlin Jensen and Bruce Hurtado.

(c) Baseline water application volumes are estimates of current water application amounts by subregion and crop and were obtained by analyzing historical data from the United States Bureau of Reclamation.

(d) Assumes low-pressure irrigation already has been implemented.

(e) Assumes implementation of fittings redesign will reduce total dynamic head by an average of approximately 12 feet and is derived from an analysis of BPA irrigation system audit records supplied by Terry Henderson and results developed by Shearer (Shearer 1983).

(f) Assiaties fittings redesign has already been implemented.

(g) Assumes implementation of mainline modification will reduce total dynamic head by an average of approximately 18 feet and is derived from an analysis of BPA irrigation system audit records supplied by Terry Henderson.

(h) Assumes all other conservation measures have been immplemented.

(i) Assumes improved irrigation scheduling will reduce water application volumes by $14 \%$ on orchard crops, $28 \%$ on potatnes. 30\% on all other crops, and is derived from analysis of the results of numerous field studies (including

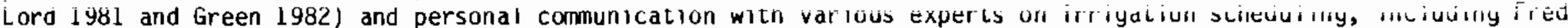
Ziari. 
TABLE 4.6. Energy-Use Data for a Sensitivity Analysis of Conservation Measures on 0ther Sprinkler Irrigation Systems

Conservation Measure

Low-Pressure Irrigation

Fittings Redesign

Mainline Modification

Improved Scheduling
Total Application Head (feet) Before Measure Implemented

$$
\begin{aligned}
& 150^{(a)} \\
& 115^{(d)} \\
& 103^{(f)} \\
& 85^{(h)}
\end{aligned}
$$

\begin{abstract}
Total Application Head (feet) After Measure Implemented
\end{abstract}

$$
\begin{aligned}
& 115^{(\mathrm{b})} \\
& 103^{(\mathrm{e})} \\
& 85^{(\mathrm{g})} \\
& \text { B5 }
\end{aligned}
$$

Volume of Water Applied Before Measure Implemented $100 \%$ of baseline(c) $100 \%$ of baseline 100\% of baseline $100 \%$ of baseline
Volume of Water

Applied After

Measure Implemented

$100 \%$ of baseline

$100 \%$ of baseline

$100 \%$ of baseline

$88 \%$ of baseline( $i)$ on orchard

$80 \%$ of baseline on potatoes

$78 \%$ of baseline on all other crops

(a) Assumes a design operating pressure of $50 \mathrm{psi}$ (115 feet of head) for a high-pressure sprinkler head, 25 feet of frictional head loss, and 10 feet of elevation head loss.

(b) Assumes a design operating pressure of $35 \mathrm{psi}$ ( 80 feet of head) for a low-pressure impact application head, 25 feet of frictional head loss, and 10 feet of elevation head loss, and is derived from analyzing data obtained from numerous published and unpublished sources, including personal communication with Dennis Kincaid and Carl Bronson.

(c) Baseline water application volumes are estimates of current water application anounts by subregion and crop and were obtained by analyzing historical data from the United States Bureau of Reclamation.

(d) Assumes low-pressure irrigation has already been implemented.

(e) Assumes implementation of fittings redesign will reduce total dynamic head by an average of approximately 12 feet and is derived from an analysis of BPA irigation system audit records supplied by Terry Henderson and results developed by Shearer (Shearer 1983).

(f) Assumes fittings redesign has already been implemented.

(g) Assumes implementation of mainline modification will reduce tatal dynamic head by an average of approximately 18 feet and is derived from an analysis of BPA irrigation system audit records supplied by Terry Henderson.

(h) Assumes all other conservation measures have been implemented.

(i) Assumes improved scheduling will reduce water application volumes by $12 \%$ on orchard crops, $20 \%$ on potatoes, and $22 \%$ on all other crops, and is derived from field studies (including Lord 1981 and Green 1982) and personal communication with various experts on irrigation scheduling, including Fred $\mathrm{Ziari}$. 
TABLE 4.7. Economic Parameters for a Sensitivity Analys is of Conservation Measure Implementation on Existing Acres

Conservation Measure

Low-Pressure
Irrigation on
Center-Pivot

Purchase and Installation 22.75 on surface water Cost per Acre $(\$ 1984)^{(a)}$

Incremental 0peration and Maintenance Cost per Acre $(\$ 1984)$ (b)

Expected Lif et ime of

Measure (years) $(c)$

Real Discount Rate $(\%)^{(d)}$
29.50 on groundwater

0

\begin{tabular}{c} 
Low-Pressure \\
Irrigation on \\
Handmove/Sideroll \\
\hline
\end{tabular}

13.50 on surface

21.50 on groundwater

0.80

3

Fittings
Redesign
3.00 on both
surf ace and
groundwater

0

3
Mainline Modification

\subsection{0 on both} surface and groundwater

3
NA

Improved Scheduling

(a) All purchase and installation costs include the costs of installing low-pressure single spray heads on center-pivot systems, low-pressure impact heads on handmove and sideroll systems (end-guns on center-pivots, where necessary), and performing any required pump modifications, including pump replacement (where necessary). Fittings redesign costs include both labor and material costs. Mainline modification includes the cost of burying the mainline. (Sources of purchase and installation cost data include personal comunications with Bruce Hurtado, Mike Monaghan and Jeff Raleigh for low-pressure irrigation; BPA Pilot Program records for fittings redesign; and personal communication with Byron Wood and Don Mulkey for mainline modification).

(b) Incremental operation and maintenance costs for low-pressure irrigation on handmove and sideroll systems is associated with the use of offsetting. Incremental 0\&M costs for improved scheduling are based on an annual peracre charge for all scheduling services and were obtained by analyzing data from several sources including personal comnurications wilh Joe Lord and Umatilla Electric Co-op reprcsentatives.

(c) No justification was found for specifying expected measure lives of less than 20 years for any of the conservation measures. Measure life is not applicable for improved scheduling because its cost is based upon an annual per-acre charge.

(d) Specified by BPA for conservation measure cost analyses. 
TABLE 4.8. Economic Parameters for a Sensitivity Analysis of Conservation Measure Implementation on New Acres

Conservation Measure

$\begin{array}{ccccc}\begin{array}{l}\text { Low-Pressure } \\ \begin{array}{l}\text { Irrigation on } \\ \text { Center-Pivot }\end{array}\end{array} & \begin{array}{c}\text { Low-Pressure } \\ \text { Irrigation on } \\ \text { Handmove/Sideroll }\end{array} & \begin{array}{c}\text { Fittings } \\ \text { Redesign }\end{array} & \begin{array}{c}\text { Mainline } \\ \text { Modification }\end{array} & \text { Improved Scheduling } \\ 0 & 0 & 0 & 7.00 & 0 \\ 20 & 0.80 & 0 & 0 & 5.50 \\ 3 & 20 & 20 & 20 & \text { NA } \\ 3 & 3 & 3 & 3 & 3\end{array}$

Purchase and Installation

Cost per Acre (\$1984) (a)

Incremental 0peration and Maintenance Cost per Acre $(\$ 1984)^{(b)}$

$\stackrel{\text { Expected Lifet ime of }}{\square \quad \text { Measure (years) }}$

Real Discount Rate (\%) (d)

(a) No additional equipment purchase and installation costs were found to be associated with any of the conservation measures except mainline modification and improved irrigation scheduling. Estimated cost for mainline modification is based upon the cost of purchasing the additional mainline materials only and does not include the cost of burying the mainline.

(b) All incremental operation and maintenance costs on new acres are estimated to be equal to those on existing acres.

(c) Measure life on new acres is estimated to be equal to those on existing acres.

(d) Specified by BPA for conservation measure cost analyses. 


\section{REFERENCES}

Bonneville Power Administration. 1983. Projections of Irrigated and Sprinkler Irrigated Acres, States and Pacific Northwest - Append ix D. Economic Studies Section.

Harrer, B.J., and A.J. Lezberg. 1984. Potential Conservation Opportunities from the Use of Low-Pressure Irrigation in the Pacific Northwest Region. PNL 5314, prepared for the Bonnevilte Power Administration, office of Conservation Planning, under a Related Services agreement with the U.S. Department of Ener:y under Contract DE-ACO6-76RLO 1830 .

Harrer, B.J., and G.L. Wilfert. 1985a. Potential Conservation Opportunities from Fittings Redesign, Mainline Modification, and Pump Efficiency Improvement: in Irrigation Systems of the Pacific Northwest. PNL -5357 , prepared for the Bonneville Power Administration, Office of Conservation Planning, under a Related Services agreement with the U.S. Department of Energy under Contract .EACO6-76RLO 1830.

Harrer, B.J., and A.J. Lezberg. 1985b. Potentjal Conservation Opportunities from the Use of Improved Scheduling in the Pacific Northwest Region. Prepared for the Bonneville Power Administration, Office of Conservation Plannini: under a Related Services agreement with the U.S. Department of Energy under Contract DE-ACO6-76RLO 1830 .

Harrer, B.J., A.J. Lezberg and G.L. Wilfert. 1985c. An Integrated Assessmen of Conservation Opportunities in the Irrigated Agriculture Sector of the Pacific Northwest Region. Prepared for the Bonneville Power Administration, Office of Conservation Planning, under a. Related Services agreement with the U.S. Department of Energy under Contract DE-ACO6-76RLO 1830.

Patton, W.P., G.L. Wilfert, B.J. Harrer, M.A. Clark and K.L. Sherman. 1982. Potential Cost Savings from Investments in Energy-Conserving Irrigation Systems. PNL-3930, Pacific Northwest Laboratory, Richland, Washington. 
APPENDIX A 
TABLE A.1. Estimated Energy-Savings Potential in Average MW and Cost Per KWh Saved in 1984 Mills for Low-Pressure Irrigation on Existing and New Center-Pivot Acres

\begin{tabular}{|c|c|c|c|c|c|c|c|c|c|c|c|c|c|}
\hline & & & & & & & reg & & & & & & \\
\hline & Source & 1 & 2 & -3 & 4 & 5 & 6 & 7 & 8 & 9 & 10 & 11 & Area \\
\hline $\begin{array}{l}\text { Energy Savings } \\
\text { on Existing } \\
\text { Acres in } \\
1984 \text { (Ave. MW) }\end{array}$ & $\begin{array}{l}\text { Surface } \\
\text { Ground } \\
\text { Total }\end{array}$ & $\begin{array}{l}\mathrm{NCP}(\mathrm{a}) \\
\mathrm{NCP} \\
\mathrm{NCP}\end{array}$ & $\begin{array}{l}0.88 \\
1.07 \\
1.95\end{array}$ & $\begin{array}{r}5.64 \\
5.36 \\
11.00\end{array}$ & $\begin{array}{l}0.29 \\
0.16 \\
0.45\end{array}$ & $\begin{array}{l}0.05 \\
0.01 \\
0.06\end{array}$ & $\begin{array}{l}1.22 \\
0.73 \\
1.95\end{array}$ & $\begin{array}{l}0.27 \\
0.67 \\
0.94\end{array}$ & $\begin{array}{l}0.38 \\
0.50 \\
0.88\end{array}$ & $\begin{array}{l}\mathrm{NCP} \\
\mathrm{NCP} \\
\mathrm{NCP}\end{array}$ & $\begin{array}{l}2.87 \\
4.36 \\
7.23\end{array}$ & $\begin{array}{l}0.48 \\
0.00 \\
0.48\end{array}$ & $\begin{array}{l}12.08 \\
12.86 \\
24.94\end{array}$ \\
\hline $\begin{array}{l}\text { Cost Per kWh } \\
\text { Saved on Exist- } \\
\text { ing Acres } \\
\text { (1984 Mills) }\end{array}$ & $\begin{array}{l}\text { Surface } \\
\text { Ground } \\
\text { Average }\end{array}$ & $\begin{array}{l}\text { NCP } \\
\text { NCP } \\
\text { NCP }\end{array}$ & $\begin{array}{l}6.70 \\
8.32 \\
7.59\end{array}$ & $\begin{array}{l}5.03 \\
6.57 \\
5.78\end{array}$ & $\begin{array}{l}6.68 \\
8.38 \\
7.28\end{array}$ & $\begin{array}{l}10.92 \\
10.23 \\
10.77\end{array}$ & $\begin{array}{l}5.27 \\
6.46 \\
5.71\end{array}$ & $\begin{array}{l}5.90 \\
7.28 \\
6.88\end{array}$ & $\begin{array}{l}6.34 \\
7.93 \\
7.24\end{array}$ & $\begin{array}{l}\text { NCP } \\
\text { NCP } \\
\text { NCP }\end{array}$ & $\begin{array}{l}6.05 \\
7.62 \\
7.00\end{array}$ & $\begin{array}{r}6.84 \\
\text { NCP } \\
6.84\end{array}$ & $\begin{array}{l}5.61 \\
7.18 \\
6.42\end{array}$ \\
\hline $\begin{array}{l}\text { Energy Savings } \\
\text { on New Acres } \\
\text { in } 2003 \\
\text { (Ave. MW) }\end{array}$ & $\begin{array}{l}\text { Surf ace } \\
\text { Ground } \\
\text { Total }\end{array}$ & $\begin{array}{l}\text { NCP } \\
\text { NCP } \\
\text { NCP }\end{array}$ & $\begin{array}{l}\text { NCP } \\
0.07 \\
0.07\end{array}$ & $\begin{array}{l}4.93 \\
0.00 \\
4.93\end{array}$ & $\begin{array}{l}0.14 \\
0.03 \\
0.17\end{array}$ & $\begin{array}{r}\text { NCP } \\
0.02 \\
0.02\end{array}$ & $\begin{array}{l}0.19 \\
0.55 \\
0.74\end{array}$ & $\begin{array}{r}\text { NCP } \\
0.13 \\
0.13\end{array}$ & $\begin{array}{r}\text { NCP } \\
0.31 \\
0.31\end{array}$ & $\begin{array}{l}\text { NCP } \\
\text { NCP } \\
\text { NCP }\end{array}$ & $\begin{array}{l}0.47 \\
0.84 \\
1.31\end{array}$ & $\begin{array}{r}\text { NCP } \\
0.09 \\
0.09\end{array}$ & $\begin{array}{l}5.73 \\
2.04 \\
7.77\end{array}$ \\
\hline $\begin{array}{l}\text { Cost Per kWh } \\
\text { Saved on New } \\
\text { Acres } \\
\text { (1984 Mjlls) }\end{array}$ & $\begin{array}{l}\text { Surface } \\
\text { Ground } \\
\text { Average }\end{array}$ & $\begin{array}{l}0.00 \\
0.00 \\
0.00\end{array}$ & $\begin{array}{l}0.00 \\
0.00 \\
0.00\end{array}$ & $\begin{array}{l}0.00 \\
0.00 \\
0.00\end{array}$ & $\begin{array}{l}0.00 \\
0.00 \\
0.00\end{array}$ & $\begin{array}{l}0.00 \\
0.00 \\
0.00\end{array}$ & $\begin{array}{l}0.00 \\
0.00 \\
0.00\end{array}$ & $\begin{array}{l}0.00 \\
0.00 \\
0.00\end{array}$ & $\begin{array}{l}0.00 \\
0.00 \\
0.00\end{array}$ & $\begin{array}{l}0.00 \\
0.00 \\
0.00\end{array}$ & $\begin{array}{l}0.00 \\
0.00 \\
0.00\end{array}$ & $\begin{array}{l}0.00 \\
0.00 \\
0.00\end{array}$ & $\begin{array}{l}0.00 \\
0.00 \\
0.00\end{array}$ \\
\hline
\end{tabular}

(a) No center-pivot acres for this subregion and water source. 
TABLE A.2. Estimated Cumulative Energy-Savings Potential (Avg. MW) in 5-Mill Increments of Cost Per kWh Saved for Low-Pressure Irrigation on Existing Center-Pivot Acres

\begin{tabular}{|c|c|c|c|c|c|c|c|c|c|c|c|}
\hline \multirow[b]{2}{*}{ Year } & \multirow[b]{2}{*}{ Water Source } & \multicolumn{10}{|c|}{ Cost Per kWh Saved } \\
\hline & & 5 & 10 & 15 & 20 & 25 & 30 & 35 & 40 & 45 & 50 \\
\hline \multirow[t]{3}{*}{1984} & Surface Water & 3.94 & 12.06 & 12.08 & 12.08 & 12.08 & 12.08 & 12.08 & 12.08 & 12.08 & 12.08 \\
\hline & Groundwater & 0.00 & 12.46 & 12.86 & 12.86 & 12.86 & 12.86 & 12.86 & 12.86 & 12.86 & 12.86 \\
\hline & Total & 3.94 & 24.52 & 24.94 & 24.94 & 24.94 & 24.94 & 24.94 & 24.94 & 24.94 & 24.94 \\
\hline
\end{tabular}


TABLE A.3. Estimated Cumulative Energy Savings

Potential (Avg. MW) in 5-Mill

Increments of Cost per kWh Saved

for Low-Pressure Irrigation

on New Center-Pivot Acres

Cost per kWh Saved

$\begin{array}{lllllllllllll}\text { Year } & 0 & & 5 & 10 & 15 & 20 & 25 & 30 & 35 & 40 & 45 & 50 \\ 1985 & 0.44 & 0.44 & 0.44 & 0.44 & 0.44 & 0.44 & 0.44 & 0.44 & 0.44 & 0.44 & 0.44 \\ 1986 & 0.82 & 0.82 & 0.82 & 0.82 & 0.82 & 0.82 & 0.82 & 0.82 & 0.82 & 0.82 & 0.82 \\ 1987 & 1.23 & 1.23 & 1.23 & 1.23 & 1.23 & 1.23 & 1.23 & 1.23 & 1.23 & 1.23 & 1.23 \\ 1988 & 1.64 & 1.64 & 1.64 & 1.64 & 1.64 & 1.64 & 1.64 & 1.64 & 1.64 & 1.64 & 1.64 \\ 1989 & 2.06 & 2.06 & 2.06 & 2.06 & 2.06 & 2.06 & 2.06 & 2.06 & 2.06 & 2.06 & 2.06 \\ 1990 & 2.45 & 2.45 & 2.45 & 2.45 & 2.45 & 2.45 & 2.45 & 2.45 & 2.45 & 2.45 & 2.45 \\ 1991 & 2.81 & 2.81 & 2.81 & 2.81 & 2.81 & 2.81 & 2.81 & 2.81 & 2.81 & 2.31 & 2.81 \\ 1992 & 3.14 & 3.14 & 3.14 & 3.14 & 3.14 & 3.14 & 3.14 & 3.14 & 3.14 & 3.14 & 3.14 \\ 1993 & 3.51 & 3.51 & 3.51 & 3.51 & 3.51 & 3.51 & 3.51 & 3.51 & 3.51 & 3.51 & 3.51 \\ 1994 & 3.89 & 3.89 & 3.89 & 3.89 & 3.89 & 3.89 & 3.89 & 3.89 & 3.89 & 3.39 & 3.89 \\ 1995 & 4.27 & 4.27 & 4.27 & 4.27 & 4.27 & 4.27 & 4.27 & 4.27 & 4.27 & 4.27 & 4.27 \\ 1996 & 4.68 & 4.68 & 4.68 & 4.68 & 4.68 & 4.68 & 4.68 & 4.68 & 4.68 & 4.38 & 4.68 \\ 1997 & 5.08 & 5.08 & 5.08 & 5.08 & 5.08 & 5.08 & 5.08 & 5.08 & 5.08 & 5.38 & 5.08 \\ 1998 & 5.49 & 5.49 & 5.49 & 5.49 & 5.49 & 5.49 & 5.49 & 5.49 & 5.49 & 5.49 & 5.49 \\ 1999 & 5.93 & 5.93 & 5.93 & 5.93 & 5.93 & 5.93 & 5.93 & 5.93 & 5.93 & 5.93 & 5.93 \\ 2000 & 6.41 & 6.41 & 6.41 & 6.41 & 6.41 & 6.41 & 6.41 & 6.41 & 6.41 & 6.41 & 6.41 \\ 2001 & 6.87 & 6.87 & 6.87 & 6.87 & 6.87 & 6.87 & 6.87 & 6.87 & 6.87 & 6.37 & 6.87 \\ 2002 & 7.30 & 7.30 & 7.30 & 7.30 & 7.30 & 7.30 & 7.30 & 7.30 & 7.30 & 7.30 & 7.30 \\ 2003 & 7.76 & 7.76 & 7.76 & 7.76 & 7.76 & 7.76 & 7.76 & 7.76 & 7.76 & 7.76 & 7.76\end{array}$


TABLE A.4. Estimated Energy-Savings Potential in Average MW and Cost Per kWh Saved in 1984 Mills for Low-Pressure lrrigation on Existing and New Handmove and Sideroll Acres

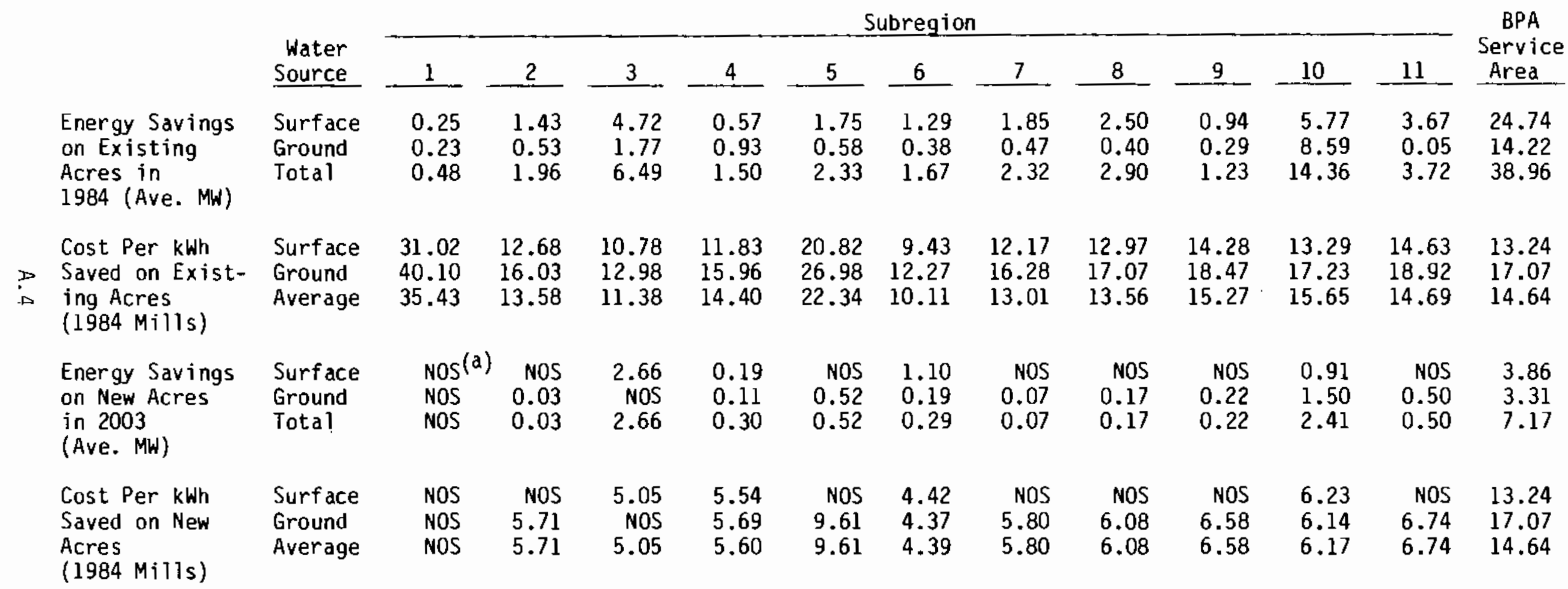

(a) No other sprinkler acres for this subregion and water source. 
TABLE A.5. Estimated Cumulative Energy Savings Potential (Avg. MW) in 5-Mill Increments of Cost Per kWh Saved for Low-Pressure Irrigation on Existing Handmove and Sideroll Acres

Cost Per kWh Saved

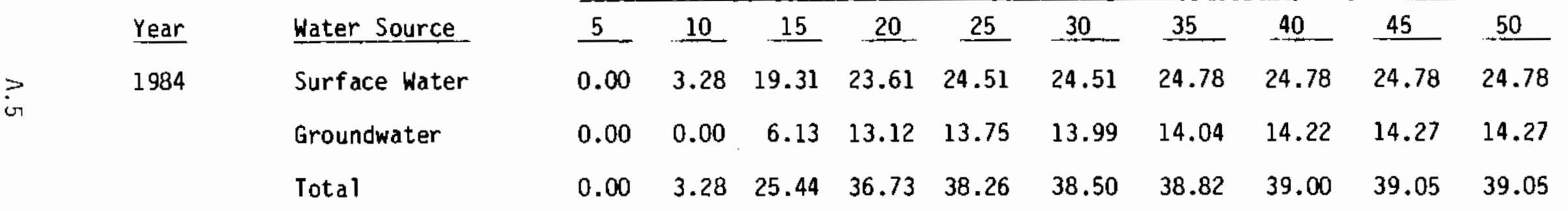


TABLE A.6. Est imated Cumulative Energy Savings

Potential (Avg. MW) in 5-Mill

Increments of Cost per $\mathrm{kWh}$ Saved

for Low-Pressure Irrigation on

New Handmove and Sideroll Acres

Cost per kwh Saved

$\begin{array}{llllllllllll}\text { Year } & 0 & 5 & 10 & 15 & 20 & 25 & 30 & 35 & 40 & 45 & 50 \\ 1985 & 0.00 & 0.09 & 0.55 & 0.56 & 0.56 & 0.56 & 0.56 & 0.56 & 0.56 & 0.56 & 0.56 \\ 1986 & 0.00 & 0.16 & 0.98 & 1.00 & 1.00 & 1.00 & 1.00 & 1.00 & 1.00 & 1.00 & 1.00 \\ 1987 & 0.00 & 1.26 & 1.44 & 1.47 & 1.47 & 1.47 & 1.47 & 1.47 & 1.47 & 1.47 & 1.47 \\ 1988 & 0.00 & 0.35 & 1.90 & 1.94 & 1.94 & 1.94 & 1.94 & 1.94 & 1.94 & 1.94 & 1.94 \\ 1989 & 0.00 & 0.43 & 2.39 & 2.43 & 2.43 & 2.43 & 2.43 & 2.43 & 2.43 & 2.43 & 2.43 \\ 1990 & 0.00 & 0.54 & 2.78 & 2.83 & 2.83 & 2.83 & 2.83 & 2.83 & 2.83 & 2.83 & 2.83 \\ 1991 & 0.00 & 0.66 & 3.04 & 3.10 & 3.10 & 3.10 & 3.10 & 3.10 & 3.10 & 3.10 & 3.10 \\ 1992 & 0.00 & 0.78 & 3.29 & 3.36 & 3.36 & 3.36 & 3.36 & 3.36 & 3.36 & 3.36 & 3.36 \\ 1993 & 0.00 & 0.92 & 3.54 & 3.63 & 3.63 & 3.63 & 3.63 & 3.63 & 3.63 & 3.63 & 3.63 \\ 1994 & 0.00 & 1.06 & 3.85 & 3.96 & 3.96 & 3.96 & 3.96 & 3.96 & 3.96 & 3.96 & 3.96 \\ 1995 & 0.00 & 1.19 & 4.14 & 4.26 & 4.26 & 4.26 & 4.26 & 4.26 & 4.26 & 4.26 & 4.26 \\ 1996 & 0.00 & 1.33 & 4.48 & 4.62 & 4.62 & 4.62 & 4.62 & 4.62 & 4.62 & 4.62 & 4.62 \\ 1997 & 0.00 & 1.46 & 4.86 & 5.01 & 5.01 & 5.01 & 5.01 & 5.01 & 5.01 & 5.01 & 5.01 \\ 1998 & 0.00 & 1.61 & 5.11 & 5.29 & 5.29 & 5.29 & 5.29 & 5.29 & 5.29 & 5.29 & 5.29 \\ 1999 & 0.00 & 1.76 & 5.49 & 5.68 & 5.68 & 5.68 & 5.68 & 5.68 & 5.68 & 5.68 & 5.68 \\ 2000 & 0.00 & 1.92 & 5.87 & 6.07 & 6.07 & 6.07 & 6.07 & 6.07 & 6.07 & 6.07 & 6.07 \\ 2001 & 0.00 & 2.08 & 6.24 & 6.46 & 6.46 & 6.46 & 6.46 & 6.46 & 6.46 & 6.46 & 6.46 \\ 2002 & 0.00 & 2.24 & 6.59 & 6.84 & 6.84 & 6.84 & 6.84 & 6.84 & 6.84 & 6.84 & 6.84 \\ 2003 & 0.00 & 2.40 & 6.96 & 7.22 & 7.22 & 7.22 & 7.22 & 7.22 & 7.22 & 7.22 & 7.22\end{array}$


IABLE A.7. Est imated Energy-Savings Potential in Average MW and Cost Per kWh Saved in 1984 Mills for Fittings Redesign on Existing and New Center-Pivot Acres

\begin{tabular}{|c|c|c|c|c|c|c|c|c|c|c|c|c|c|}
\hline & & & & & & & bregic & & & & & & BPA \\
\hline & Source & 1 & 2 & 3 & 4 & 5 & 6 & 7 & 8 & 9 & 10 & 11 & Area \\
\hline $\begin{array}{l}\text { Energy Savings } \\
\text { on Existing } \\
\text { Acres in } \\
1984 \text { (Ave. MW) }\end{array}$ & $\begin{array}{l}\text { Surface } \\
\text { Ground } \\
\text { Total }\end{array}$ & $\begin{array}{l}N C P(a) \\
N C P \\
N C P\end{array}$ & $\begin{array}{l}0.12 \\
0.18 \\
0.30\end{array}$ & $\begin{array}{l}0.95 \\
0.91 \\
1.86\end{array}$ & $\begin{array}{l}0.04 \\
0.03 \\
0.07\end{array}$ & $\begin{array}{l}\text { NCP } \\
\text { NCP } \\
\text { NCP }\end{array}$ & $\begin{array}{l}0.25 \\
0.14 \\
0.39\end{array}$ & $\begin{array}{l}0.04 \\
0.10 \\
0.14\end{array}$ & $\begin{array}{l}0.06 \\
0.07 \\
0.13\end{array}$ & $\begin{array}{l}N C P \\
N C P \\
N C P\end{array}$ & $\begin{array}{l}0.50 \\
0.76 \\
1.26\end{array}$ & $\begin{array}{l}0.10 \\
0.00 \\
0.10\end{array}$ & $\begin{array}{l}2.06 \\
2.19 \\
4.25\end{array}$ \\
\hline $\begin{array}{l}\text { Cost Per kWh } \\
\text { Saved on Exist- } \\
\text { ing Acres } \\
\text { (1984 Mills) }\end{array}$ & $\begin{array}{l}\text { Surface } \\
\text { Ground } \\
\text { Average }\end{array}$ & $\begin{array}{l}\text { NCP } \\
\text { NCP } \\
\text { NCP }\end{array}$ & $\begin{array}{l}5.16 \\
4.93 \\
5.03\end{array}$ & $\begin{array}{l}3.87 \\
3.90 \\
3.88\end{array}$ & $\begin{array}{l}5.14 \\
4.97 \\
5.08\end{array}$ & $\begin{array}{l}8.49 \\
6.07 \\
7.97\end{array}$ & $\begin{array}{l}4.05 \\
3.83 \\
3.97\end{array}$ & $\begin{array}{l}4.54 \\
4.32 \\
4.38\end{array}$ & $\begin{array}{l}4.87 \\
4.71 \\
4.79\end{array}$ & $\begin{array}{l}\text { NCP } \\
\text { NCP } \\
\text { NCP }\end{array}$ & $\begin{array}{l}4.66 \\
4.52 \\
4.58\end{array}$ & $\begin{array}{r}5.21 \\
\mathrm{NCP} \\
5.21\end{array}$ & $\begin{array}{l}4.31 \\
4.26 \\
4.28\end{array}$ \\
\hline $\begin{array}{l}\text { Energy Savings } \\
\text { on New Acres } \\
\text { in } 2003 \\
\text { (Ave. MW) }\end{array}$ & $\begin{array}{l}\text { Surface } \\
\text { Ground } \\
\text { Total }\end{array}$ & $\begin{array}{l}\text { NCP } \\
\text { NCP } \\
\text { NCP }\end{array}$ & $\begin{array}{l}\text { NCP } \\
0.01 \\
0.01\end{array}$ & $\begin{array}{l}0.85 \\
0.00 \\
0.85\end{array}$ & $\begin{array}{l}0.03 \\
0.00 \\
0.03\end{array}$ & $\begin{array}{l}0.00 \\
0.00 \\
0.00\end{array}$ & $\begin{array}{l}0.04 \\
0.09 \\
0.13\end{array}$ & $\begin{array}{l}0.00 \\
0.02 \\
0.02\end{array}$ & $\begin{array}{l}0.00 \\
0.05 \\
0.05\end{array}$ & $\begin{array}{l}\text { NCP } \\
\text { NCP } \\
\text { NCP }\end{array}$ & $\begin{array}{l}0.08 \\
0.14 \\
0.22\end{array}$ & $\begin{array}{l}0.00 \\
0.02 \\
0.02\end{array}$ & $\begin{array}{l}1.00 \\
0.33 \\
1.33\end{array}$ \\
\hline $\begin{array}{l}\text { Cost Per kWh } \\
\text { Saved on New } \\
\text { Acres } \\
\text { (1984 Mills) }\end{array}$ & $\begin{array}{l}\text { Surface } \\
\text { Ground } \\
\text { Average }\end{array}$ & $\begin{array}{l}0.00 \\
0.00 \\
0.00\end{array}$ & $\begin{array}{l}0.00 \\
0.00 \\
0.00\end{array}$ & $\begin{array}{l}0.00 \\
0.00 \\
0.00\end{array}$ & $\begin{array}{l}0.00 \\
0.00 \\
0.00\end{array}$ & $\begin{array}{l}0.00 \\
0.00 \\
0.00\end{array}$ & $\begin{array}{l}0.00 \\
0.00 \\
0.00\end{array}$ & $\begin{array}{l}0.00 \\
0.00 \\
0.00\end{array}$ & $\begin{array}{l}0.00 \\
0.00 \\
0.00\end{array}$ & $\begin{array}{l}0.00 \\
0.00 \\
0.00\end{array}$ & $\begin{array}{l}0.00 \\
0.00 \\
0.00\end{array}$ & $\begin{array}{l}0.00 \\
0.00 \\
0.00\end{array}$ & $\begin{array}{r}0.00 \\
0.00 \\
0.00\end{array}$ \\
\hline
\end{tabular}

(a) No center-pivot acres for this subregion and water source. 
TABLE A.8. Estimated Cumulative Energy-Savings Potential (Avg. MW) in 5-Mill Increments of Cost Per kWh Saved for Fittings Redesign on Existing Center-Pivot Acres

\begin{tabular}{|c|c|c|c|c|c|c|c|c|c|c|c|}
\hline \multirow[t]{4}{*}{ Year } & Water Source & 5 & 10 & 15 & 20 & 25 & 30 & 35 & 40 & 45 & 50 \\
\hline & Surface Water & 1.83 & 2.07 & 2.07 & 2.07 & 2.07 & 2.07 & 2.07 & 2.07 & 2.07 & 2.07 \\
\hline & Groundwater & 1.95 & 2.19 & 2.19 & 2.19 & 2.19 & 2.19 & 2.19 & 2.19 & 2.19 & 2.19 \\
\hline & Total & 3.78 & 4.26 & 4.26 & 4.26 & 4.26 & 4.26 & 4.26 & 4.26 & 4.26 & 4.26 \\
\hline
\end{tabular}


TA8LE A.9. Estimated Cumulative Energy Savings

Potential (Avg. MW) in 5-Mill

Increments of Cost per kWh Saved

for Fittings Redesign on

New Center-Pivot Acres

Cost per kWh Saved

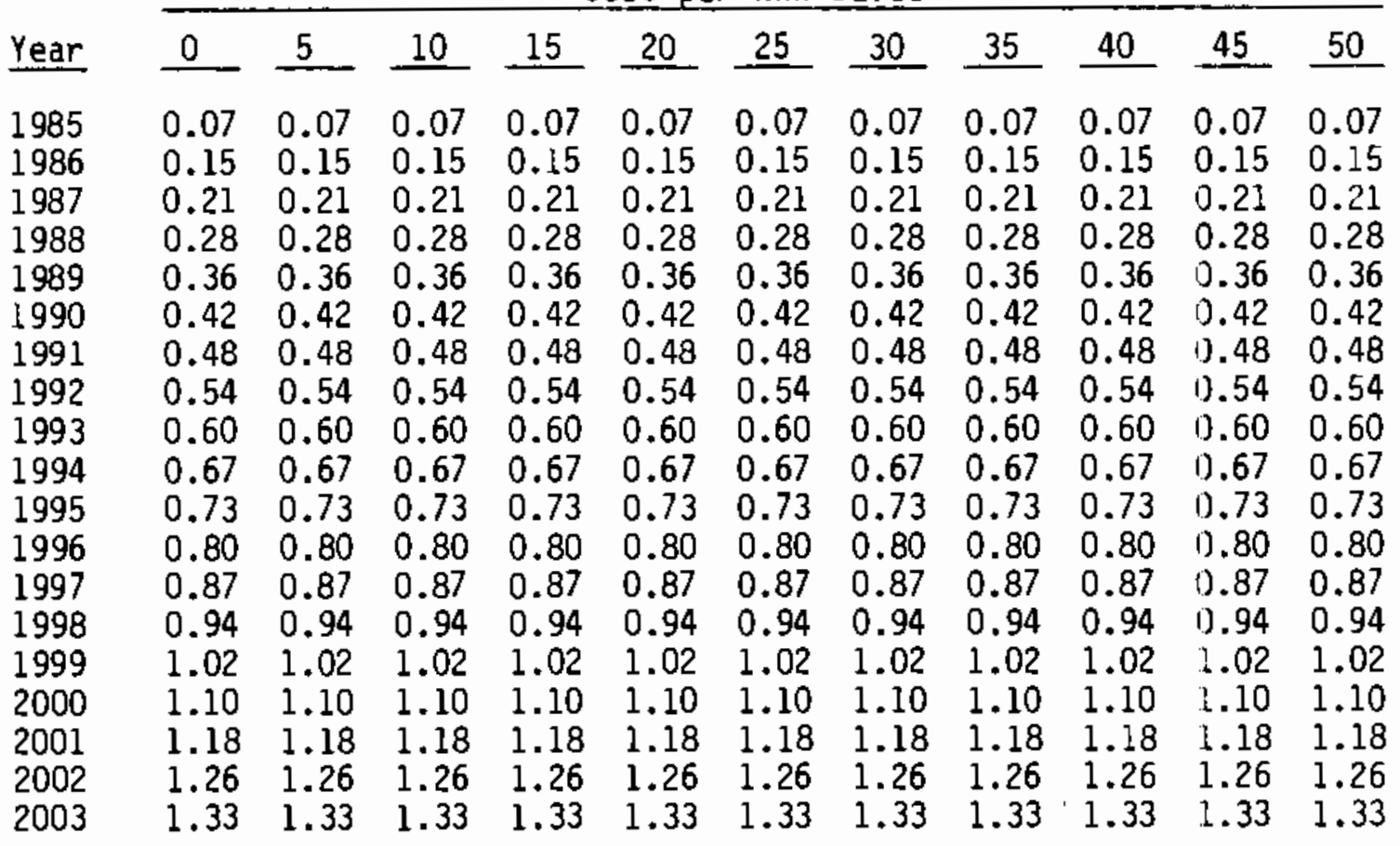


TABLE A.10. Estimated Energy-Savings Potential in Average MW and Cost Per kWh Saved in 1984 Mills for Fittings Redesign on Existing and New Other Sprinkler Acres

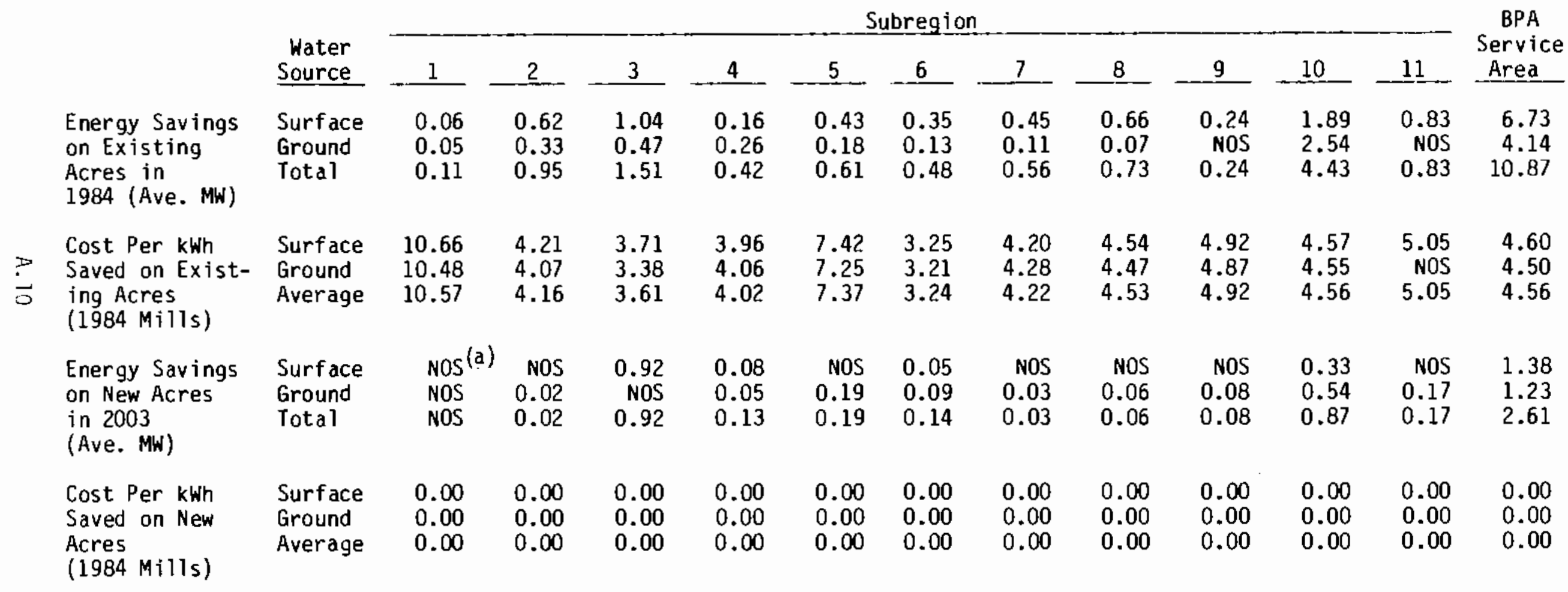

(a) No other sprinkler acres for this subregion and water source. 
TABLE A.11. Estimated Cumulative Energy Savings Potential (Avg. MW) in 5-Mill Increments of Cost Per kWh Saved for Fittings Redesign on Existing Other Sprinkler Acres

\begin{tabular}{|c|c|c|c|c|c|c|c|c|c|c|c|}
\hline \multirow[b]{2}{*}{ Year } & \multirow[b]{2}{*}{ Water Source } & \multicolumn{10}{|c|}{ Cost Per kWh Saved } \\
\hline & & 5 & 10 & 15 & 20 & 25 & 30 & 35 & 40 & 45 & 50 \\
\hline \multirow[t]{3}{*}{1984} & Surface Water & 5.13 & 6.66 & 6.73 & 6.73 & 6.73 & 6.73 & 6.73 & 6.73 & 6.73 & 6.73 \\
\hline & Groundwater & 2.74 & 4.05 & 4.11 & 4.11 & 4.11 & 4.11 & 4.11 & 4.11 & 4.11 & 4.11 \\
\hline & Total & 7.87 & 10.71 & 10.84 & 10.84 & 10.84 & 10.84 & 10.84 & 10.84 & 10.84 & 10.84 \\
\hline
\end{tabular}


TABLE A.12. Est imated Cumulative Energy Savings

Potential (Avg. MW) in 5-Mill

Increments of Cost per kWh Saved

for Fittings Redesign on New

Other Sprink ler Acres

Cost per kWh Saved

$\begin{array}{llllllllllll}\text { Year } & 0 & 5 & 10 & 15 & 20 & 25 & 30 & 35 & 40 & 45 & 50 \\ 1985 & 0.20 & 0.20 & 0.20 & 0.20 & 0.20 & 0.20 & 0.20 & 0.20 & 0.20 & 0.20 & 0.20 \\ 1986 & 0.36 & 0.36 & 0.36 & 0.36 & 0.36 & 0.36 & 0.36 & 0.36 & 0.36 & 0.36 & 0.36 \\ 1987 & 0.52 & 0.52 & 0.52 & 0.52 & 0.52 & 0.52 & 0.52 & 0.52 & 0.52 & 0.52 & 0.52 \\ 1988 & 0.69 & 0.69 & 0.69 & 0.69 & 0.69 & 0.69 & 0.69 & 0.69 & 0.69 & 0.69 & 0.69 \\ 1989 & 0.86 & 0.86 & 0.86 & 0.86 & 0.86 & 0.86 & 0.86 & 0.86 & 0.86 & 0.86 & 0.86 \\ 1990 & 1.01 & 1.01 & 1.01 & 1.01 & 1.01 & 1.01 & 1.01 & 1.01 & 1.01 & 1.01 & 1.01 \\ 1991 & 1.10 & 1.10 & 1.10 & 1.10 & 1.10 & 1.10 & 1.10 & 1.10 & 1.10 & 1.10 & 1.10 \\ 1992 & 1.20 & 1.20 & 1.20 & 1.20 & 1.20 & 1.20 & 1.20 & 1.20 & 1.20 & 1.20 & 1.20 \\ 1993 & 1.30 & 1.30 & 1.30 & 1.30 & 1.30 & 1.30 & 1.30 & 1.30 & 1.30 & 1.30 & 1.30 \\ 1994 & 1.41 & 1.41 & 1.41 & 1.41 & 1.41 & 1.41 & 1.41 & 1.41 & 1.41 & 1.41 & 1.41 \\ 1995 & 1.52 & 1.52 & 1.52 & 1.52 & 1.52 & 1.52 & 1.52 & 1.52 & 1.52 & 1.52 & 1.52 \\ 1996 & 1.65 & 1.65 & 1.65 & 1.65 & 1.65 & 1.65 & 1.65 & 1.65 & 1.65 & 1.65 & 1.65 \\ 1997 & 1.80 & 1.80 & 1.80 & 1.80 & 1.80 & 1.80 & 1.80 & 1.80 & 1.80 & 1.80 & 1.80 \\ 1998 & 1.90 & 1.90 & 1.90 & 1.90 & 1.90 & 1.90 & 1.90 & 1.90 & 1.90 & 1.90 & 1.90 \\ 1999 & 2.04 & 2.04 & 2.04 & 2.04 & 2.04 & 2.04 & 2.04 & 2.04 & 2.04 & 2.04 & 2.04 \\ 2000 & 2.18 & 2.18 & 2.18 & 2.18 & 2.18 & 2.18 & 2.18 & 2.18 & 2.18 & 2.18 & 2.18 \\ 2001 & 2.33 & 2.33 & 2.33 & 2.33 & 2.33 & 2.33 & 2.33 & 2.33 & 2.33 & 2.33 & 2.33 \\ 2002 & 2.45 & 2.45 & 2.45 & 2.45 & 2.45 & 2.45 & 2.45 & 2.45 & 2.45 & 2.45 & 2.45 \\ 2003 & 2.60 & 2.60 & 2.60 & 2.60 & 2.60 & 2.60 & 2.60 & 2.60 & 2.60 & 2.60 & 2.60\end{array}$


TABLE A.13. Estimated Energy-Savings Potential in Average MW and Cost Per kWh Saved in 1984 Mills for Mainline Modification on Existing and New Center-Pivot Acres

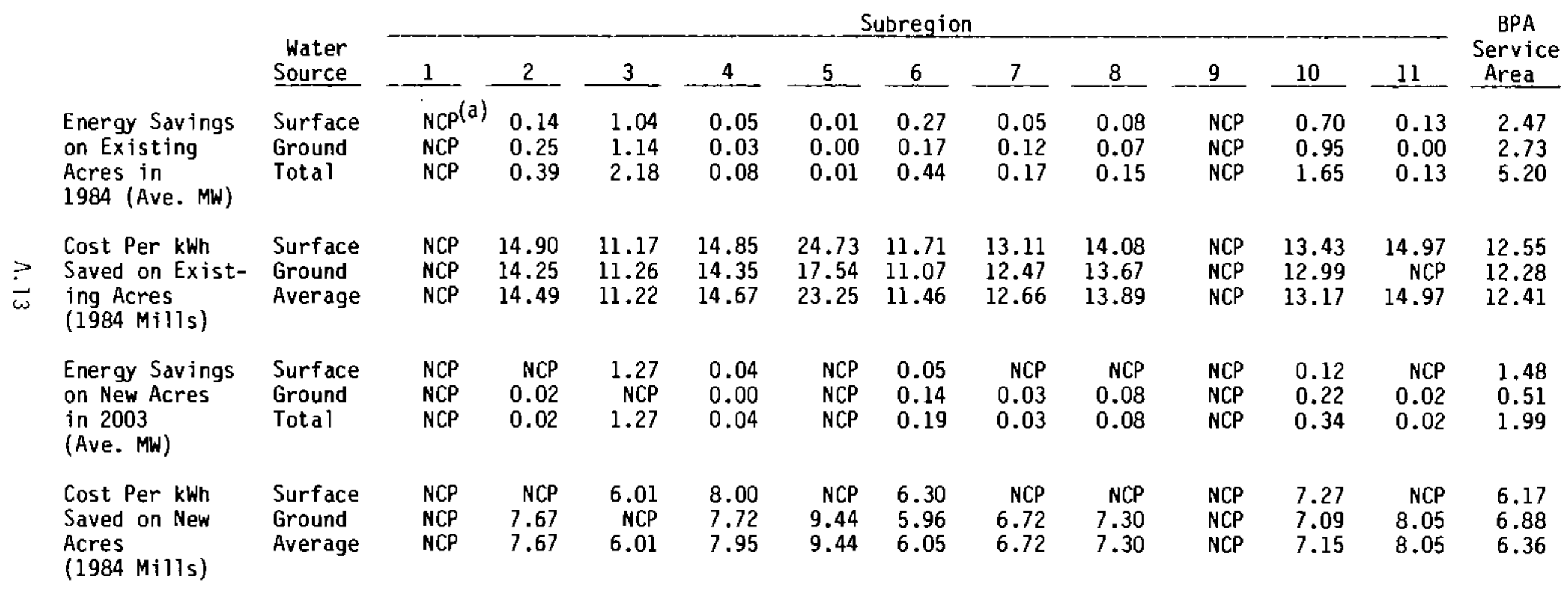

(a) No center-pivot acres for this subregion and water source. 
TABLE A.14. Estimated Cumulative Energy-Savings Potential (Avg. MW) in 5-Mill Increments of Cost Per kWh Saved for Mainline Modification on Existing Center-Pivot Acres

\begin{tabular}{|c|c|c|c|c|c|c|c|c|c|c|c|c|}
\hline \multirow{2}{*}{\multicolumn{2}{|c|}{ Year }} & \multirow[b]{2}{*}{ Water Source } & \multicolumn{10}{|c|}{-_ost Per kwh saved } \\
\hline & & & 5 & 10 & 15 & 20 & 25 & 30 & 35 & 40 & 45 & 50 \\
\hline \multirow[t]{3}{*}{$\stackrel{\vec{P}}{\vec{P}}$} & 1984 & Surface Water & 0.00 & 0.58 & 2.15 & 2.44 & 2.45 & 2.46 & 2.46 & 2.46 & 2.46 & 2.46 \\
\hline & & Groundwater & 0.00 & 0.65 & 2.46 & 2.72 & 2.72 & 2.72 & 2.72 & 2.72 & 2.72 & 2.72 \\
\hline & & Total & 0.00 & 1.23 & 4.61 & 5.16 & 5.17 & 5.18 & 5.18 & 5.18 & 5.18 & 5.18 \\
\hline
\end{tabular}


TABLE A.15. Est imated Cumulative Energy Savings

Potential (Avg. MW) in 5-Mill

Increments of Cost per kWh Saved

for Mainline Modification

on New Center-Pivot Acres

Cost per kWh Saved

\begin{tabular}{|c|c|c|c|c|c|c|c|c|c|c|c|}
\hline Yea & 0 & 5 & 10 & 15 & 20 & 25 & 30 & 35 & 40 & 45 & 50 \\
\hline & & 02 & 0.11 & 0.11 & 0.11 & 0.1 & 0.11 & 0.11 & 0.11 & 0.11 & \\
\hline & 0.00 & 0.04 & 0.21 & 0.21 & 0.21 & 0.2 & 0.21 & 0.21 & & & \\
\hline & 0.00 & 0.05 & 0.31 & 0.31 & 0.31 & 0.31 & 0.31 & 0.31 & 0.31 & & \\
\hline & .00 & 0.07 & 0.42 & 0.42 & 0.42 & 0.42 & 0.42 & 0.42 & 0.42 & 0 . & \\
\hline & 0 & 0.09 & 0.53 & 0.53 & 0.5 & 0. & 0. & 0. & 0.5 & & \\
\hline & 0.00 & 0.10 & 0.63 & 0.63 & 0.63 & 0.8 & 0.63 & 0.63 & 0.6 & & \\
\hline & 0.0 & 0.13 & 0.73 & 0.7 & 0.73 & 0.7 & 0 . & 0 . & 0 . & & \\
\hline & .0 & 0.15 & 0.81 & 0.81 & 0.81 & 0.8 & 0.81 & 0 . & 0. & 0. & \\
\hline & b & 0.16 & 0.90 & 0.90 & 0.90 & 0. & 0. & & & & \\
\hline & .00 & 0.19 & 1.00 & 1.00 & 1.00 & 1.00 & 1.00 & 1.00 & 1.0 & 1.30 & \\
\hline & ) & 0.2 & 1.10 & 1.10 & 1.10 & 1.1 & 1.10 & & & & \\
\hline & 0.00 & 0.23 & 1.20 & 1.20 & 1.20 & 1.20 & 1.20 & 1.20 & 1.20 & 1.20 & \\
\hline & 0 & 0.25 & 1.31 & 1.31 & 1.31 & 1.3 & 1.31 & & & & \\
\hline & 0.00 & 0.28 & 1.40 & 1.40 & 1.40 & 1.40 & 1.40 & 1.40 & 1.40 & 1.40 & \\
\hline & 0.00 & 0.30 & 1.52 & 1.52 & 1.52 & 1.5 & 1.52 & 1.52 & 1.52 & 1.52 & \\
\hline & & 0. & 1.64 & 1.6 & 1.6 & 1 . & 1 . & & & 1.64 & \\
\hline & 0.0 & 0.3 & 1.76 & 1.7 & 1.7 & 1.7 & 1.7 & 1.7 & 1.7 & 1.76 & \\
\hline & & 0.3 & 1.87 & 1. & 1.8 & 1. & 1. & & 1. & 1.37 & \\
\hline & 0.00 & 0.39 & 1.99 & 1.9 & 1.99 & 1.9 & 1.99 & 1.99 & 1.99 & 1.99 & \\
\hline
\end{tabular}


TABLE A.16. Estimated Energy-Savings Potential in Average MW and Cost Per kWh Saved in 1984 Mills for Mainline Modification on Existing and New Other Sprinkler Acres

\begin{tabular}{|c|c|c|c|c|c|c|c|c|c|c|c|c|c|}
\hline & & & & & & & bregi & & & & & & \\
\hline & Source & 1 & 2 & 3 & 4 & 5 & 6 & 7 & 8 & _- 9 & 10 & 11 & Area \\
\hline $\begin{array}{l}\text { Energy Savings } \\
\text { on Existing } \\
\text { Acres in } \\
1984 \text { (Ave. MW) }\end{array}$ & $\begin{array}{l}\text { Surface } \\
\text { Ground } \\
\text { Total }\end{array}$ & $\begin{array}{l}0.07 \\
0.06 \\
0.13\end{array}$ & $\begin{array}{l}0.76 \\
0.48 \\
1.24\end{array}$ & $\begin{array}{l}1.13 \\
0.60 \\
1.73\end{array}$ & $\begin{array}{l}0.17 \\
0.30 \\
0.47\end{array}$ & $\begin{array}{l}0.50 \\
0.23 \\
0.73\end{array}$ & $\begin{array}{l}0.37 \\
0.17 \\
0.54\end{array}$ & $\begin{array}{l}0.52 \\
0.13 \\
0.65\end{array}$ & $\begin{array}{l}0.86 \\
0.05 \\
0.91\end{array}$ & $\begin{array}{l}0.30 \\
0.00 \\
0.30\end{array}$ & $\begin{array}{l}2.55 \\
2.83 \\
5.38\end{array}$ & $\begin{array}{l}0.94 \\
0.00 \\
0.94\end{array}$ & $\begin{array}{r}8.17 \\
4.85 \\
13.02\end{array}$ \\
\hline $\begin{array}{l}\text { Cost Per kwh } \\
\text { Saved on Exist- } \\
\text { ing Acres } \\
(1984 \mathrm{Mills})\end{array}$ & $\begin{array}{l}\text { Surface } \\
\text { Ground } \\
\text { Average }\end{array}$ & $\begin{array}{l}30.78 \\
30.27 \\
30.53\end{array}$ & $\begin{array}{l}12.11 \\
11.77 \\
11.98\end{array}$ & $\begin{array}{r}10.71 \\
9.74 \\
10.37\end{array}$ & $\begin{array}{l}11.44 \\
11.71 \\
11.61\end{array}$ & $\begin{array}{l}21.42 \\
20.85 \\
21.22\end{array}$ & $\begin{array}{l}9.39 \\
9.28 \\
9.36\end{array}$ & $\begin{array}{l}12.15 \\
12.36 \\
12.19\end{array}$ & $\begin{array}{l}13.14 \\
12.91 \\
13.12\end{array}$ & $\begin{array}{l}14.21 \\
14.16 \\
14.21\end{array}$ & $\begin{array}{l}13.22 \\
13.24 \\
13.23\end{array}$ & $\begin{array}{r}14.60 \\
\text { NOS } \\
14.60\end{array}$ & $\begin{array}{l}13.32 \\
13.05 \\
13.22\end{array}$ \\
\hline $\begin{array}{l}\text { Energy Savings } \\
\text { on New Acres } \\
\text { in } 2003 \\
\text { (Ave. Mw) }\end{array}$ & $\begin{array}{l}\text { Surface } \\
\text { Ground } \\
\text { Total }\end{array}$ & $\begin{array}{l}\text { NOS }(a) \\
\text { NOS } \\
\text { NOS }\end{array}$ & $\begin{array}{l}\text { NOS } \\
0.04 \\
0.04\end{array}$ & $\begin{array}{r}1.39 \\
\text { NOS } \\
1.39\end{array}$ & $\begin{array}{l}0.12 \\
0.07 \\
0.19\end{array}$ & $\begin{array}{l}\text { NOS } \\
0.29 \\
0.29\end{array}$ & $\begin{array}{l}0.07 \\
0.13 \\
0.20\end{array}$ & $\begin{array}{l}\text { NOS } \\
0.04 \\
0.04\end{array}$ & $\begin{array}{l}\text { NOS } \\
0.09 \\
0.09\end{array}$ & $\begin{array}{l}\text { NOS } \\
0.11 \\
0.11\end{array}$ & $\begin{array}{l}0.49 \\
0.81 \\
1.30\end{array}$ & $\begin{array}{l}\text { NOS } \\
0.26 \\
0.26\end{array}$ & $\begin{array}{l}2.07 \\
1.84 \\
3.91\end{array}$ \\
\hline $\begin{array}{l}\text { Cost Per kWh } \\
\text { Saved on New } \\
\text { Acres } \\
\text { (1984 Mills) }\end{array}$ & $\begin{array}{l}\text { Surface } \\
\text { Ground } \\
\text { Average }\end{array}$ & $\begin{array}{l}\text { NOS } \\
\text { NOS } \\
\text { NOS }\end{array}$ & $\begin{array}{r}\text { NOS } \\
6.34 \\
6.34\end{array}$ & $\begin{array}{r}5.77 \\
\text { NOS } \\
5.77\end{array}$ & $\begin{array}{l}6.16 \\
6.31 \\
6.21\end{array}$ & $\begin{array}{r}\text { NOS } \\
11.39 \\
11.39\end{array}$ & $\begin{array}{l}5.05 \\
5.00 \\
5.02\end{array}$ & $\begin{array}{r}\text { NOS } \\
6.66 \\
6.66\end{array}$ & $\begin{array}{r}\text { NOS } \\
6.95 \\
6.95\end{array}$ & $\begin{array}{l}\text { NOS } \\
7.53 \\
7.53\end{array}$ & $\begin{array}{l}7.11 \\
7.01 \\
7.05\end{array}$ & $\begin{array}{r}\text { NOS } \\
7.71 \\
7.71\end{array}$ & $\begin{array}{l}6.09 \\
7.64 \\
6.82\end{array}$ \\
\hline
\end{tabular}

(a) No other sprinkler acres for this subregion and water source. 
TABLE A.17. Est imated Cumulative Energy-Savings Potential (Avg. MW) in 5-Mill Increments of Cost Per kWh Saved for Mainline Modification on Existing Other Sprinkler Acres

Cost Per kWh Saved

\begin{tabular}{|c|c|c|c|c|c|c|c|c|c|c|c|}
\hline \multirow[t]{4}{*}{ Year } & Water Source & 5 & 10 & 15 & 20 & 25 & 30 & 35 & 40 & 45 & 50 \\
\hline & Surface Water & 0.00 & 0.76 & 6.18 & 7.79 & 8.03 & 8.11 & 8.19 & 8.19 & 8.19 & 8.19 \\
\hline & Groundwater & 0.00 & 0.86 & 4.32 & 4.47 & 4.61 & 4.66 & 4.67 & 4.67 & 4.67 & 4.67 \\
\hline & Total & 0.00 & 1.62 & 10.50 & 12.26 & 12.64 & 12.77 & 12.86 & 12.86 & 12.86 & 12.86 \\
\hline
\end{tabular}


TABLE A.18. Estimated Cumulative Energy Savings

Potential (Avg. MW) in 5-Mill

Increments of Cost per kWh Saved

for Mainline Modification on

New Other Sprinkler Acres

Cost per XWh Saved

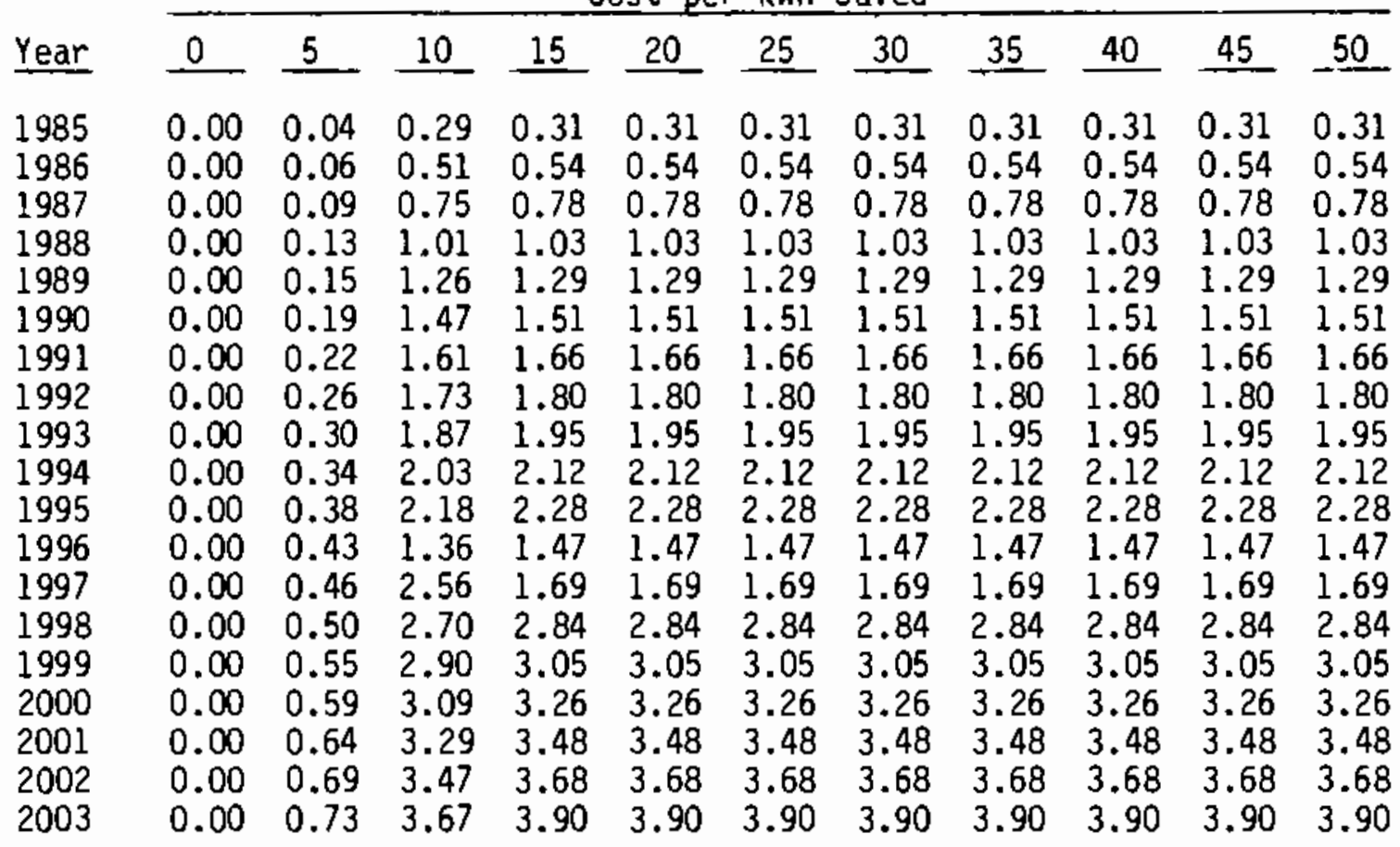


TABLE A.19. Estimated Energy-Savings Potential in Average MW and Cost Per kWh Saved in 1984 Mills for Improved Scheduling on Existing and New Center-Pivot WaterSensitive Crop (a) Acres

\begin{tabular}{|c|c|c|c|c|c|c|c|c|c|c|c|c|c|}
\hline & & & & & & & ubregic & & & & & & \\
\hline & Source & 1 & 2 & 3 & 4 & 5 & 6 & 7 & 8 & 9 & 10 & 11 & Area \\
\hline $\begin{array}{l}\text { Energy Savings } \\
\text { on Existing } \\
\text { Acres in } \\
1984 \text { (Ave. MW) }\end{array}$ & $\begin{array}{l}\text { Surface } \\
\text { Ground } \\
\text { Total }\end{array}$ & $\begin{array}{l}\mathrm{NCP}(\mathrm{b}) \\
\mathrm{NCP} \\
\mathrm{NCP}\end{array}$ & $\begin{array}{l}0.22 \\
0.42 \\
0.64\end{array}$ & $\begin{array}{l}0.93 \\
3.03 \\
3.96\end{array}$ & $\begin{array}{l}0.00 \\
0.00 \\
0.00\end{array}$ & $\begin{array}{l}0.01 \\
0.00 \\
0.01\end{array}$ & $\begin{array}{l}0.47 \\
0.28 \\
0.75\end{array}$ & $\begin{array}{l}0.01 \\
0.00 \\
0.01\end{array}$ & $\begin{array}{l}0.02 \\
0.04 \\
0.06\end{array}$ & $\begin{array}{l}0.00 \\
0.00 \\
0.00\end{array}$ & $\begin{array}{l}0.45 \\
2.53 \\
2.98\end{array}$ & $\begin{array}{l}0.00 \\
0.00 \\
0.00\end{array}$ & $\begin{array}{l}2.11 \\
6.30 \\
8.41\end{array}$ \\
\hline $\begin{array}{l}\text { Cost Per kWh } \\
\text { Saved on Exist- } \\
\text { ing Acres } \\
\text { (1984 Mills) }\end{array}$ & $\begin{array}{l}\text { Surface } \\
\text { Ground } \\
\text { Average }\end{array}$ & $\begin{array}{l}\text { NCP } \\
\text { NCP } \\
\text { NCP }\end{array}$ & $\begin{array}{l}52.98 \\
18.75 \\
30.32\end{array}$ & $\begin{array}{r}51.49 \\
9.93 \\
19.66\end{array}$ & $\begin{array}{l}\text { NCP } \\
\text { NCP } \\
\text { NCP }\end{array}$ & $\begin{array}{r}124.30 \\
\text { NCP } \\
124.30\end{array}$ & $\begin{array}{l}16.99 \\
16.14 \\
16.67\end{array}$ & $\begin{array}{l}66.40 \\
32.83 \\
54.39\end{array}$ & $\begin{array}{l}78.76 \\
50.32 \\
59.64\end{array}$ & $\begin{array}{l}\text { NCP } \\
\text { NCP } \\
\text { NCP }\end{array}$ & $\begin{array}{l}62.45 \\
18.69 \\
25.32\end{array}$ & $\begin{array}{l}81.51 \\
38.25 \\
80.18\end{array}$ & $\begin{array}{l}46.96 \\
14.58 \\
22.67\end{array}$ \\
\hline $\begin{array}{l}\text { Energy Savings } \\
\text { on New Acres } \\
\text { in } 2003 \\
\text { (Ave. MW) }\end{array}$ & $\begin{array}{l}\text { Surface } \\
\text { Ground } \\
\text { Total }\end{array}$ & $\begin{array}{l}\text { NCP } \\
\text { NCP } \\
\text { NCP }\end{array}$ & $\begin{array}{l}0.00 \\
0.03 \\
0.03\end{array}$ & $\begin{array}{l}0.77 \\
0.00 \\
0.77\end{array}$ & $\begin{array}{l}0.00 \\
0.00 \\
0.00\end{array}$ & $\begin{array}{l}0.00 \\
0.00 \\
0.00\end{array}$ & $\begin{array}{l}0.06 \\
0.20 \\
0.26\end{array}$ & $\begin{array}{l}0.00 \\
0.00 \\
0.00\end{array}$ & $\begin{array}{l}0.00 \\
0.02 \\
0.02\end{array}$ & $\begin{array}{l}0.00 \\
0.00 \\
0.00\end{array}$ & $\begin{array}{l}0.07 \\
0.41 \\
0.48\end{array}$ & $\begin{array}{l}0.00 \\
0.00 \\
0.00\end{array}$ & $\begin{array}{l}0.90 \\
0.66 \\
1.56\end{array}$ \\
\hline $\begin{array}{l}\text { Cost Per kWh } \\
\text { Saved on New } \\
\text { Acres } \\
\text { (1984 Mills) }\end{array}$ & $\begin{array}{l}\text { Surf ace } \\
\text { Ground } \\
\text { Average }\end{array}$ & $\begin{array}{l}\text { NCP } \\
\text { NCP } \\
\text { NCP }\end{array}$ & $\begin{array}{r}\text { NCP } \\
18.74 \\
18.74\end{array}$ & $\begin{array}{r}52.34 \\
\text { NCP } \\
52.34\end{array}$ & $\begin{array}{l}\text { NCP } \\
\text { NCP } \\
\text { NCP }\end{array}$ & $\begin{array}{l}\text { NCP } \\
\text { NCP } \\
\text { NCP }\end{array}$ & $\begin{array}{l}17.26 \\
16.27 \\
16.50\end{array}$ & $\begin{array}{r}\text { NCP } \\
32.82 \\
32.82\end{array}$ & $\begin{array}{r}\text { NCP } \\
50.79 \\
50.79\end{array}$ & $\begin{array}{l}\text { NCP } \\
\text { NCP } \\
\text { NCP }\end{array}$ & $\begin{array}{l}63.05 \\
19.08 \\
25.37\end{array}$ & $\begin{array}{r}\text { NCP } \\
38.54 \\
38.54\end{array}$ & $\begin{array}{l}50.71 \\
19.09 \\
37.33\end{array}$ \\
\hline
\end{tabular}

(a) For purposes of this study, water-sensitive crops are defined as potatoes, corn and other miscellaneous crops. (b) No center-pivot acres for this subregion and water source. 
TABLE A.20. Estimated Cumulative Energy-Savings Potential (Avg. MW) in 5-Mill Increments of Cost Per kWh Saved for Improved Scheduling on Existing Center-Pivot WaterSensitive Crop (a) Acres

Cost Per kWh Saved

\begin{tabular}{|c|c|c|c|c|c|c|c|c|c|c|c|}
\hline \multirow[b]{2}{*}{ Year } & \multirow[b]{2}{*}{ Water Source } & \multicolumn{10}{|c|}{1} \\
\hline & & 5 & 10 & 15 & 20 & 25 & 30 & -35 & 40 & 45 & 50 \\
\hline \multirow[t]{3}{*}{1984} & Surface Water & 0.00 & 0.00 & 0.13 & 0.47 & 0.47 & 0.47 & 0.47 & 0.47 & 0.47 & 1.10 \\
\hline & Groundwater & 0.00 & 1.80 & 3.09 & 5.92 & 6.27 & 6.27 & 6.27 & 6.27 & 6.27 & 6.31 \\
\hline & Tota] & 0.00 & 1.80 & 3.22 & 6.39 & 6.74 & 6.74 & 6.74 & 6.74 & 6.74 & 7.41 \\
\hline
\end{tabular}

(a) For purposes of this study, water-sensitive crops are defined as potatoes, corn, and other miscellaneous crops. 
TA8LE A.21. Estimated Cumulative Energy Savings

Potential (Avg. MW) in 5-Mill

Increments of Cost per kWh Saved

for Improved Scheduling on

New Gepter-Pivot Water-Sensitive

Crop $(a)$ Acres

Cost per kWh Saved

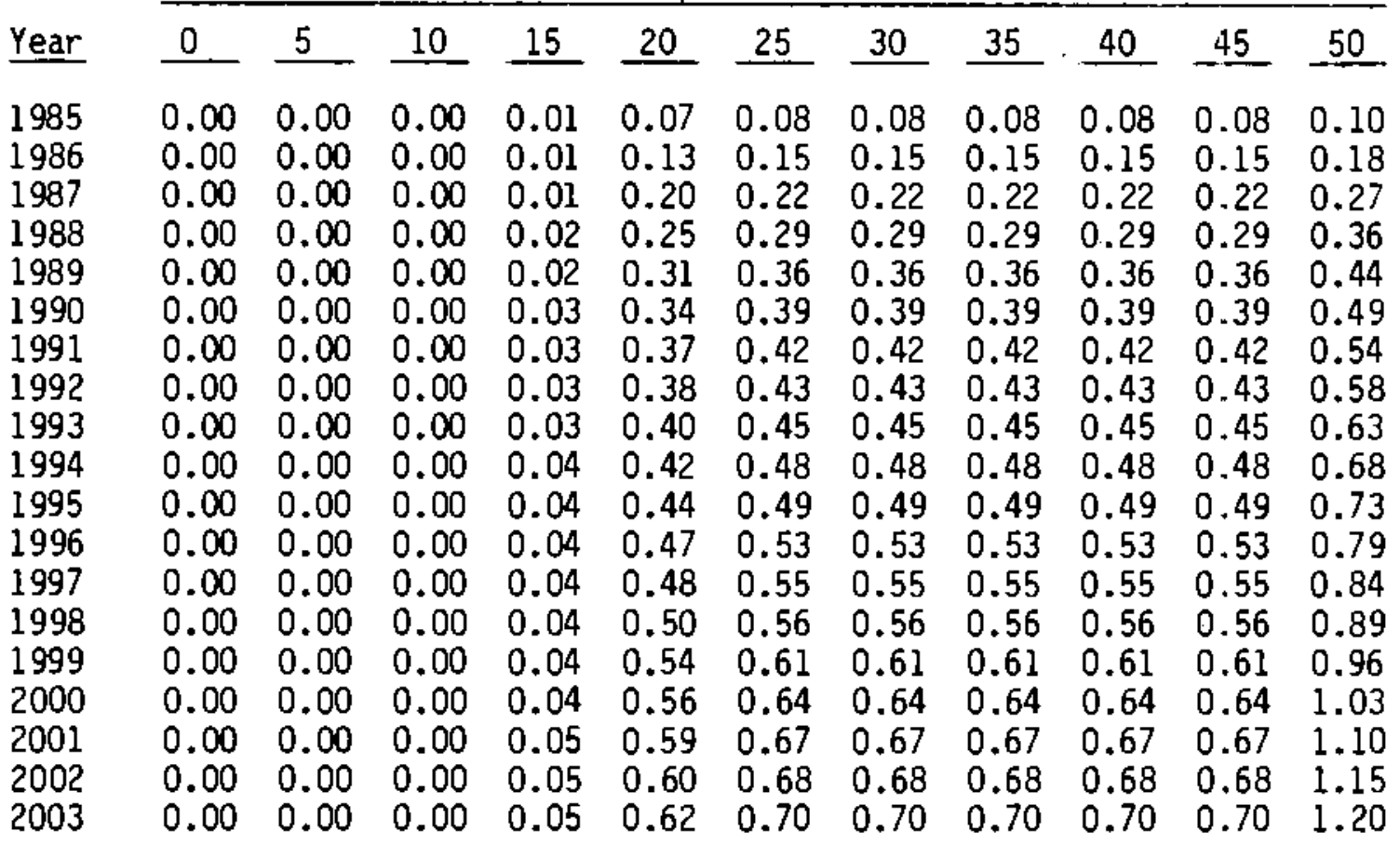

(a) For purposes of this study, water-sensitive crops are defined as potatoes, corn and other miscellaneous crops. 
TABLE A.22. Estimated Energy-Savings Potential in Average MW and Cost Per kWh Saved in $1984 \mathrm{Mi}$ lls for Improved Scheduling on Existing and New Center-Pivot Non-Water-Sensitive Crop (a) Acres

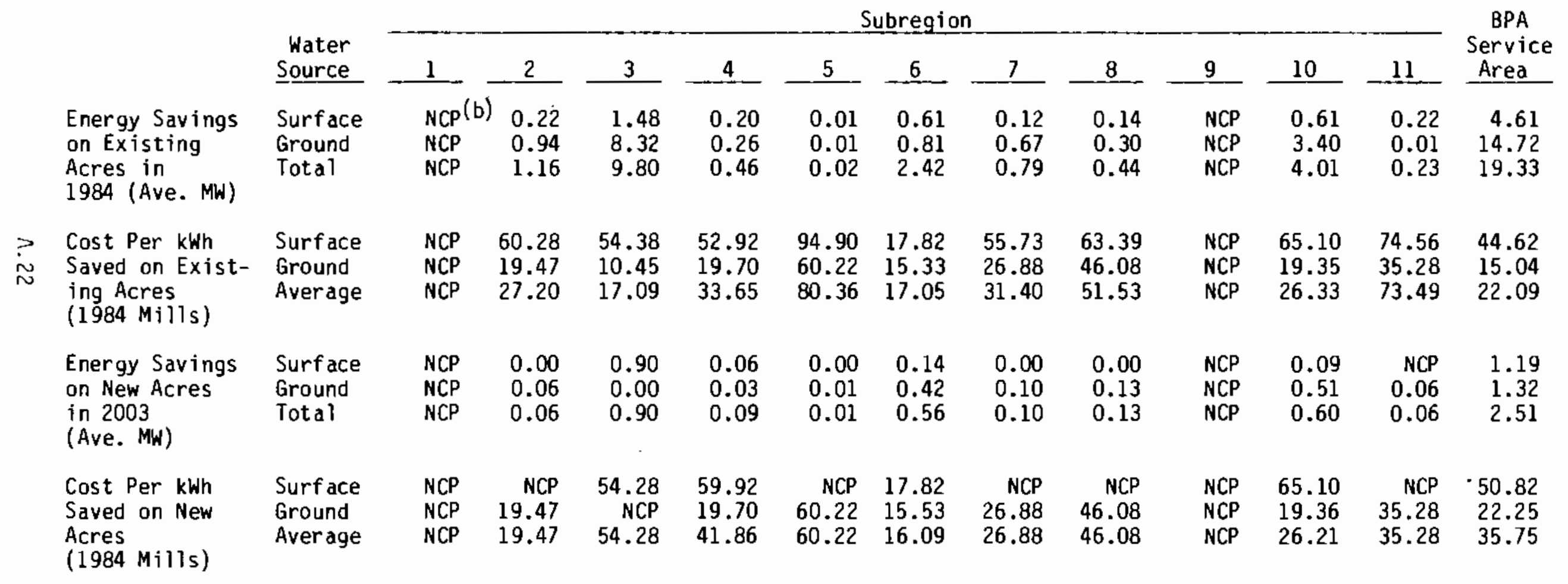

(a) For purposes of this study, non-water-sensitive crops are defined as wheat, hay, orchard and other miscellaneous crops.

(b) No center-pivot acres for this subregion and water source. 
TABLE A.23. Estimated Cumulative Energy-Savings Potential (Avg. MW) in 5-Mill Increments of Cost Per kWh Saved for Improved Scheduling on Existing Center-Pivot Non-Water-Sensitive Crop (a) Acres

\begin{tabular}{|c|c|c|c|c|c|c|c|c|c|c|c|}
\hline \multirow[b]{2}{*}{ Year } & \multirow[b]{2}{*}{ Water Source } & \multicolumn{10}{|c|}{ Cost Per kwh Saved } \\
\hline & & 5 & 10 & 15 & 20 & 25 & 30 & 35 & -40 & 45 & 50 \\
\hline \multirow[t]{3}{*}{1984} & Surface Water & 0.00 & 0.00 & 0.70 & 0.70 & 1.61 & 1.61 & 1.61 & 1.68 & 2.39 & 2.61 \\
\hline & Groundwater & 0.00 & 4.36 & 8.89 & 11.80 & 13.73 & 14.32 & 14.33 & 14.40 & 14.67 & 14.67 \\
\hline & Total & 0.00 & 4.36 & 9.59 & 12.50 & 15.34 & 15.93 & 15.94 & 16.08 & 17.06 & 17.28 \\
\hline
\end{tabular}

(a) For purposes of this study, non-water-sensitive crops are defined as wheat, hay, orchard, and other miscellaneous crops. 
TABLE A.24. Estimated Cumulative Energy Savings

Potential (Avg. MW) in 5-Mill

Increments of cost per $\mathrm{kWh}$ Saved

for Improved Scheduling on

Center-Pivot Non-Water-Sensitive

Crop (a) Acres

Cost per kWh Saved

\begin{tabular}{llllllllllll} 
Year & $\underline{0}$ & \multicolumn{1}{l}{10} & $\underline{10}$ & $\underline{15}$ & 20 & 25 & 30 & 35 & 40 & 45 & 50 \\
1985 & 0.00 & 0.00 & 0.00 & 0.03 & 0.10 & 0.13 & 0.13 & 0.13 & 0.13 & 0.16 & 0.17 \\
1986 & 0.00 & 0.00 & 0.00 & 0.06 & 0.18 & 0.23 & 0.23 & 0.23 & 0.23 & 0.29 & 0.30 \\
1987 & 0.00 & 0.00 & 0.00 & 0.09 & 0.26 & 0.34 & 0.34 & 0.34 & 0.34 & 0.43 & 0.44 \\
1988 & 0.00 & 0.00 & 0.00 & 0.12 & 0.35 & 0.45 & 0.45 & 0.45 & 0.45 & 0.57 & 0.59 \\
1989 & 0.00 & 0.00 & 0.00 & 0.15 & 0.43 & 0.55 & 0.55 & 0.56 & 0.56 & 0.61 & 0.72 \\
1990 & 0.00 & 0.00 & 0.00 & 0.18 & 0.50 & 0.62 & 0.62 & 0.63 & 0.65 & 0.82 & 0.84 \\
1991 & 0.00 & 0.00 & 0.00 & 0.20 & 0.52 & 0.66 & 0.68 & 0.69 & 0.71 & 0.91 & 0.93 \\
1992 & 0.00 & 0.00 & 0.00 & 0.21 & 0.54 & 0.69 & 0.71 & 0.73 & 0.73 & 0.95 & 0.99 \\
1993 & 0.00 & 0.00 & 0.00 & 0.22 & 0.57 & 0.74 & 0.76 & 0.78 & 0.78 & 1.04 & 1.08 \\
1994 & 0.00 & 0.00 & 0.00 & 0.22 & 0.58 & 0.77 & 0.79 & 0.81 & 0.83 & 1.10 & 1.15 \\
1995 & 0.00 & 0.00 & 0.00 & 0.24 & 0.62 & 0.81 & 0.85 & 0.87 & 0.89 & 1.18 & 1.24 \\
1996 & 0.00 & 0.00 & 0.00 & 0.26 & 0.66 & 0.86 & 0.90 & 0.92 & 0.94 & 1.26 & 1.33 \\
1997 & 0.00 & 0.00 & 0.00 & 0.26 & 0.67 & 0.88 & 0.93 & 0.96 & 0.97 & 1.33 & 1.41 \\
1998 & 0.00 & 0.00 & 0.00 & 0.27 & 0.70 & 0.92 & 0.98 & 1.01 & 1.04 & 1.42 & 1.49 \\
1999 & 0.00 & 0.00 & 0.00 & 0.29 & 0.74 & 0.98 & 1.04 & 1.08 & 1.10 & 1.51 & 1.60 \\
2000 & 0.00 & 0.00 & 0.00 & 0.29 & 0.77 & 1.05 & 1.12 & 1.15 & 1.18 & 1.62 & 1.72 \\
2001 & 0.00 & 0.00 & 0.00 & 0.30 & 0.80 & 1.11 & 1.18 & 1.23 & 1.26 & 1.73 & 1.83 \\
2002 & 0.00 & 0.00 & 0.00 & 0.31 & 0.82 & 1.13 & 1.21 & 1.26 & 1.29 & 1.79 & 1.90 \\
2003 & 0.00 & 0.00 & 0.00 & 0.32 & 0.85 & 1.17 & 1.26 & 1.31 & 1.34 & 1.88 & 1.99
\end{tabular}

(a) For purposes of this study, non-water-sensitive crops are defined as wheat, hay, orchard and other miscellaneous crops. 
TABLE A.25. Estimated Energy-Savings Potential in Average MW and Cost Per kWh Saved jn 1984 Mills for Improyed Scheduling in Existing and New Other Sprinkler(a) Water-Sensitive Crop $(b)$ Acres

\begin{tabular}{|c|c|c|c|c|c|c|c|c|c|c|c|c|c|}
\hline & \multirow{2}{*}{$\begin{array}{r}\text { Water } \\
\text { Source }\end{array}$} & \multicolumn{11}{|c|}{ Subregion } & \multirow{2}{*}{$\begin{array}{c}\text { BPA } \\
\text { Service } \\
\text { Area }\end{array}$} \\
\hline & & 1 & 2 & 3 & 4 & 5 & 6 & 7 & 8 & 9 & 10 & 11 & \\
\hline $\begin{array}{l}\text { Energy Savings } \\
\text { on Existing } \\
\text { Acres in } \\
1984 \text { (Ave. MW) }\end{array}$ & $\begin{array}{l}\text { Surface } \\
\text { Ground } \\
\text { Total }\end{array}$ & $\begin{array}{l}0.02 \\
0.03 \\
0.05\end{array}$ & $\begin{array}{l}0.14 \\
0.22 \\
0.36\end{array}$ & $\begin{array}{l}0.14 \\
1.46 \\
1.60\end{array}$ & $\begin{array}{l}0.07 \\
0.20 \\
0.27\end{array}$ & $\begin{array}{l}0.41 \\
0.17 \\
0.58\end{array}$ & $\begin{array}{l}0.19 \\
0.10 \\
0.29\end{array}$ & $\begin{array}{l}0.10 \\
0.08 \\
0.18\end{array}$ & $\begin{array}{l}0.14 \\
0.03 \\
0.17\end{array}$ & $\begin{array}{l}0.04 \\
0.02 \\
0.06\end{array}$ & $\begin{array}{l}0.76 \\
2.92 \\
3.68\end{array}$ & $\begin{array}{l}0.03 \\
0.00 \\
0.03\end{array}$ & $\begin{array}{l}2.04 \\
5.23 \\
7.27\end{array}$ \\
\hline $\begin{array}{l}\text { Cost Per kwh } \\
\text { Saved on Exist- } \\
\text { ing Acres } \\
\text { (1984 Mills) }\end{array}$ & $\begin{array}{l}\text { Surface } \\
\text { Ground } \\
\text { Average }\end{array}$ & $\begin{array}{l}185.09 \\
148.72 \\
166.18\end{array}$ & $\begin{array}{l}56.59 \\
21.71 \\
37.26\end{array}$ & $\begin{array}{l}54.80 \\
12.01 \\
21.40\end{array}$ & $\begin{array}{l}46.04 \\
18.89 \\
25.61\end{array}$ & $\begin{array}{r}120.93 \\
94.41 \\
113.24\end{array}$ & $\begin{array}{l}16.53 \\
16.11 \\
16.40\end{array}$ & $\begin{array}{l}66.59 \\
35.69 \\
52.38\end{array}$ & $\begin{array}{l}83.30 \\
59.80 \\
79.54\end{array}$ & $\begin{array}{l}71.46 \\
35.44 \\
60.33\end{array}$ & $\begin{array}{l}77.57 \\
26.46 \\
37.11\end{array}$ & $\begin{array}{l}89.18 \\
45.70 \\
88.50\end{array}$ & $\begin{array}{l}73.43 \\
24.86 \\
40.22\end{array}$ \\
\hline $\begin{array}{l}\text { Energy Savings } \\
\text { on New Acres } \\
\text { in } 2003 \\
\text { (Ave. MW) }\end{array}$ & $\begin{array}{l}\text { Surface } \\
\text { Ground } \\
\text { Total }\end{array}$ & $\begin{array}{l}\text { NOS }(c) \\
\text { NOS } \\
\text { NOS }\end{array}$ & $\begin{array}{l}0.00 \\
0.01 \\
0.01\end{array}$ & $\begin{array}{l}0.30 \\
0.00 \\
0.30\end{array}$ & $\begin{array}{l}0.02 \\
0.03 \\
0.05\end{array}$ & $\begin{array}{l}0.00 \\
0.16 \\
0.16\end{array}$ & $\begin{array}{l}0.03 \\
0.06 \\
0.09\end{array}$ & $\begin{array}{l}0.00 \\
0.01 \\
0.01\end{array}$ & $\begin{array}{l}0.00 \\
0.01 \\
0.01\end{array}$ & $\begin{array}{l}0.00 \\
0.02 \\
0.02\end{array}$ & $\begin{array}{l}0.11 \\
0.52 \\
0.63\end{array}$ & $\begin{array}{l}0.00 \\
0.01 \\
0.01\end{array}$ & $\begin{array}{l}0.46 \\
0.83 \\
1.29\end{array}$ \\
\hline $\begin{array}{l}\text { Cost Per kwh } \\
\text { Saved on New } \\
\text { Acres } \\
\text { (1984 Mills) }\end{array}$ & $\begin{array}{l}\text { Surface } \\
\text { Ground } \\
\text { Average }\end{array}$ & $\begin{array}{l}\text { NOS } \\
\text { NOS } \\
\text { NOS }\end{array}$ & $\begin{array}{r}\text { NOS } \\
21.71 \\
21.71\end{array}$ & $\begin{array}{r}57.18 \\
\text { NOS } \\
57.18\end{array}$ & $\begin{array}{l}46.04 \\
18.89 \\
31.49\end{array}$ & $\begin{array}{r}\text { NOS } \\
94.41 \\
94.41\end{array}$ & $\begin{array}{l}19.60 \\
16.17 \\
17.49\end{array}$ & $\begin{array}{r}\text { NOS } \\
35.77 \\
35.77\end{array}$ & $\begin{array}{r}\text { NOS } \\
59.90 \\
59.90\end{array}$ & $\begin{array}{r}\text { NOS } \\
35.65 \\
35.65\end{array}$ & $\begin{array}{l}77.69 \\
26.57 \\
35.77\end{array}$ & $\begin{array}{r}\text { NOS } \\
46.10 \\
46.10\end{array}$ & $\begin{array}{l}58.77 \\
39.68 \\
46.63\end{array}$ \\
\hline
\end{tabular}

(a) Other sprinkler irrigation systems are handmove, sideroll, and solid-set systems.

(b) For purposes of this study, water-sensitive crops are defined as potatoes, corn and other miscellaneous crops.

(c) No other sprinkler acres for this subregion and water source. 
TABLE A.26. Estimated Cumulative Energy-Savings Potential (Avg. MW) in 5-Mill Increments of Cost Per kWh Saved for Improved Scheduling on Existing Other Sprinkler (a) Water-Sensitive Crop (b) Acres

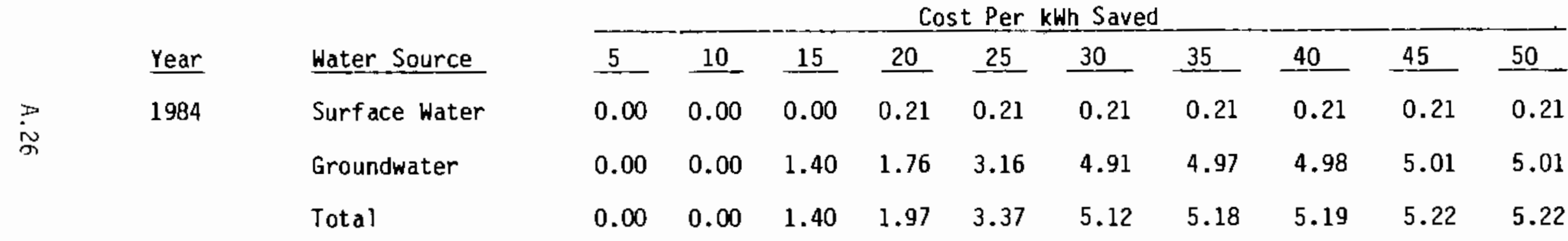

(a) 0ther sprinkler irrigation systems are handmove, sideroll, and soljd-set systems.

(b) For purposes of this study, water-sensitive crops are defined as potatoes, corn, and other miscellaneous crops. 
TABLE A.27. Est imated Cumulative Energy Savings

Potential (Avg. MW) in 5-Mill

Increments of Cost per kWh Saved

for Improved Schedu]ing on

New Other Sprinkler (a) Water-

Sensitive Crop $(b)$ Acres

Cost per kWh Saved

\begin{tabular}{lllllllllllll} 
Year & 0 & 5 & 10 & 15 & 20 & 25 & 30 & 35 & 40 & 45 & 50 \\
\hline 1985 & 0.00 & 0.00 & 0.00 & 0.00 & 0.01 & 0.03 & 0.08 & 0.08 & 0.08 & 0.08 & 0.08 \\
1986 & 0.00 & 0.00 & 0.00 & 0.00 & 0.01 & 0.06 & 0.14 & 0.14 & 0.14 & 0.15 & 0.15 \\
1987 & 0.00 & 0.00 & 0.00 & 0.00 & 0.02 & 0.09 & 0.20 & 0.20 & 0.21 & 0.21 & 0.21 \\
1988 & 0.00 & 0.00 & 0.00 & 0.00 & 0.02 & 0.12 & 0.27 & 0.28 & 0.28 & 0.28 & 0.28 \\
1989 & 0.00 & 0.00 & 0.00 & 0.00 & 0.03 & 0.15 & 0.33 & 0.34 & 0.35 & 0.35 & 0.35 \\
1990 & 0.00 & 0.00 & 0.00 & 0.00 & 0.04 & 0.16 & 0.34 & 0.36 & 0.37 & 0.37 & 0.37 \\
1991 & 0.00 & 0.00 & 0.00 & 0.00 & 0.04 & 0.17 & 0.37 & 0.38 & 0.39 & 0.39 & 0.39 \\
1992 & 0.00 & 0.00 & 0.00 & 0.00 & 0.05 & 0.18 & 0.38 & 0.39 & 0.40 & 0.40 & 0.40 \\
1993 & 0.00 & 0.00 & 0.00 & 0.00 & 0.06 & 0.19 & 0.40 & 0.41 & 0.42 & 0.43 & 0.43 \\
1994 & 0.00 & 0.00 & 0.00 & 0.00 & 0.06 & 0.20 & 0.42 & 0.43 & 0.44 & 0.45 & 0.45 \\
1995 & 0.00 & 0.00 & 0.00 & 0.00 & 0.06 & 0.22 & 0.44 & 0.46 & 0.47 & 0.47 & 0.48 \\
1996 & 0.00 & 0.00 & 0.00 & 0.00 & 0.06 & 0.23 & 0.47 & 0.49 & 0.50 & 0.50 & 0.50 \\
1997 & 0.00 & 0.00 & 0.00 & 0.00 & 0.07 & 0.24 & 0.49 & 0.51 & 0.52 & 0.52 & 0.53 \\
1998 & 0.00 & 0.00 & 0.00 & 0.00 & 0.07 & 0.24 & 0.51 & 0.52 & 0.53 & 0.54 & 0.54 \\
1999 & 0.00 & 0.00 & 0.00 & 0.00 & 0.08 & 0.27 & 0.55 & 0.57 & 0.58 & 0.58 & 0.59 \\
2000 & 0.00 & 0.00 & 0.00 & 0.00 & 0.09 & 0.29 & 0.59 & 0.61 & 0.62 & 0.62 & 0.63 \\
2001 & 0.00 & 0.00 & 0.00 & 0.00 & 0.09 & 0.30 & 0.61 & 0.63 & 0.64 & 0.64 & 0.65 \\
2002 & 0.00 & 0.00 & 0.00 & 0.00 & 0.09 & 0.32 & 0.64 & 0.65 & 0.66 & 0.67 & 0.67 \\
2003 & 0.00 & 0.00 & 0.00 & 0.00 & 0.10 & 0.33 & 0.65 & 0.67 & 0.68 & 0.69 & 0.69
\end{tabular}

(a) Other sprinkler irrigation systems are handmove, sideroll, and solidset systems.

(b) For purposes of this study, water-sensitive crops are defined as potatoes, corn and other miscellaneous crops. 
IABLE A.28. Estimated Energy-Savings Potential in Average MW and Cost Per kWh Saved jn 1984 Mills for. Improved Scheduling on Existing and New Other Sprinkler $(a)$ Non-Water-Sensitive Crop $(6)$ Acres

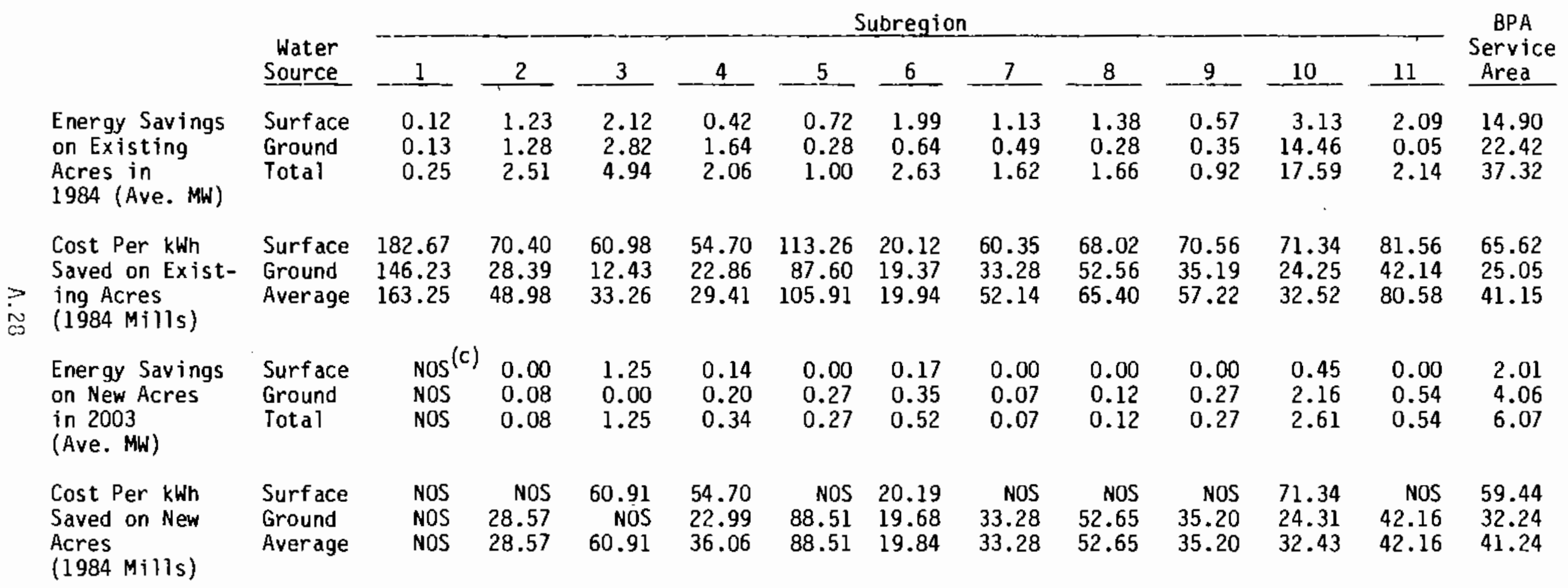

\footnotetext{
(a) 0ther sprinkler irrigation systems are handmove, sideroll, and solid-set systems.

(b) For purposes of this study, non-water-sensitive crops are defined as wheat, hay, orchard and other miscellaneous crops.

(c) No other sprinkler acres for this subregion and water source.
} 
TABLE A.29. Estimated Cumulative Energy-Savings Potential (Avg. MW) in 5-Mill Increments of Cost Per kWh Saved for Improved Scheduling on Existing Other Sprinkler Non-Water-Sensitive Crop (b) Acres

\begin{tabular}{|c|c|c|c|c|c|c|c|c|c|c|c|}
\hline \multirow[b]{2}{*}{ Year } & \multirow[b]{2}{*}{ Water Source } & \multicolumn{10}{|c|}{ Cost Per kwh Saved } \\
\hline & & 5 & 10 & 15 & 20 & 25 & 30 & 35 & 40 & 45 & 50 \\
\hline \multirow[t]{3}{*}{1984} & Surface Water & 0.00 & 0.00 & 0.00 & 1.37 & 1.37 & 1.99 & 1.99 & 1.99 & 2.20 & 3.19 \\
\hline & Groundwater & 0.00 & 0.00 & 2.33 & 4.19 & 13.00 & 20.59 & 21.08 & 21.72 & 21.72 & 21.93 \\
\hline & Total & 0.00 & 0.00 & 2.33 & 5.56 & 14.37 & 22.58 & 23.07 & 23.71 & 23.92 & 25.12 \\
\hline
\end{tabular}

(a) Other sprinkier irrigation systems are handmove, sideroll, and solid-set systems.

(b) For purposes of this study, non-water-sensitive crops are defined as wheat, hay, orchard and other miscellaneous crops. 
TABLE A.30. Estimated Cumulative Energy Savings

Potential (Av9. MW) in 5-Mill

Increments of cost per kWh Saved

for Improved Schedu)ing on

New Other Sprink]er a) Non-Water-

Sensitive Crop $(b)$ Acres

Cost per kWh Saved

\begin{tabular}{llllllllllll} 
Year & \multicolumn{1}{l}{0} & 5 & 10 & 15 & 20 & 25 & 30 & 35 & 40 & 45 & 50 \\
1985 & 0.00 & 0.00 & 0.00 & 0.00 & 0.03 & 0.20 & 0.34 & 0.39 & 0.40 & 0.42 & 0.45 \\
1986 & 0.00 & 0.00 & 0.00 & 0.00 & 0.05 & 0.35 & 0.60 & 0.68 & 0.70 & 0.73 & 0.78 \\
1987 & 0.00 & 0.00 & 0.00 & 0.00 & 0.08 & 0.52 & 0.87 & 0.99 & 1.02 & 1.07 & 1.16 \\
1988 & 0.00 & 0.00 & 0.00 & 0.00 & 0.12 & 0.68 & 1.16 & 1.31 & 1.36 & 1.41 & 1.53 \\
1989 & 0.00 & 0.00 & 0.00 & 0.00 & 0.14 & 0.85 & 1.43 & 1.63 & 1.69 & 1.75 & 1.89 \\
1990 & 0.00 & 0.00 & 0.00 & 0.00 & 0.18 & 0.90 & 1.51 & 1.75 & 1.83 & 1.91 & 2.10 \\
1991 & 0.00 & 0.00 & 0.00 & 0.00 & 0.21 & 0.98 & 1.64 & 1.88 & 1.97 & 2.07 & 2.29 \\
1992 & 0.00 & 0.00 & 0.00 & 0.00 & 0.22 & 1.01 & 1.70 & 1.94 & 2.05 & 2.14 & 2.39 \\
1993 & 0.00 & 0.00 & 0.00 & 0.00 & 0.24 & 1.07 & 1.81 & 2.05 & 2.18 & 2.28 & 2.56 \\
1994 & 0.00 & 0.00 & 0.00 & 0.00 & 0.25 & 1.13 & 1.90 & 2.14 & 2.30 & 2.41 & 2.72 \\
1995 & 0.00 & 0.00 & 0.00 & 0.00 & 0.28 & 1.19 & 1.99 & 2.24 & 2.42 & 2.54 & 2.89 \\
1996 & 0.00 & 0.00 & 0.00 & 0.00 & 0.30 & 1.26 & 2.12 & 2.37 & 2.57 & 2.68 & 3.07 \\
1997 & 0.00 & 0.00 & 0.00 & 0.00 & 0.31 & 1.32 & 2.22 & 2.48 & 2.71 & 2.83 & 3.25 \\
1998 & 0.00 & 0.00 & 0.00 & 0.00 & 0.33 & 1.36 & 2.19 & 2.55 & 2.81 & 2.94 & 3.40 \\
1999 & 0.00 & 0.00 & 0.00 & 0.00 & 0.35 & 1.46 & 2.47 & 2.71 & 3.02 & 3.15 & 3.64 \\
2000 & 0.00 & 0.00 & 0.00 & 0.00 & 0.38 & 1.57 & 2.66 & 2.89 & 3.24 & 3.37 & 3.91 \\
2001 & 0.00 & 0.00 & 0.00 & 0.00 & 0.41 & 1.64 & 2.76 & 3.00 & 3.40 & 3.54 & 4.11 \\
2002 & 0.00 & 0.00 & 0.00 & 0.00 & 0.42 & 1.68 & 2.85 & 3.08 & 3.53 & 3.67 & 4.29 \\
2003 & 0.00 & 0.00 & 0.00 & 0.00 & 0.44 & 1.74 & 2.94 & 3.18 & 3.67 & 3.82 & 4.48
\end{tabular}

(a) Other sprinkler irrigation systems are handmove, sideroll, and solidset systems.

(b) For purposes of this study, non-water-sensitive crops are defined as wheat, hay, orchard and other miscellaneous crops. 


\section{DISTRIBUTION}

No. of

Copies

OFFSITE

2 Curt Hickman

Bonneville Power Administration

P.0. Box 3621

Portland, OR 97208

30 DOE Technical Information Center

Mary Corrigan

Department of Energy

Forrestal Building

Washington, D.C. 20585

ONSITE

DOE Richland Operations Office

H.E. Ransom

14 Pacific Northwest Laboratory

R.C. Adams

A.J. Lezberg

G.L. Wilfert

B.J. Harrer (4)

Publishing Coordination (2)

Technical Information (5) 
